CIRJE-F-629

\title{
Socio-Economic Studies on Suicide: A Survey
}

Joe Chen

National Chengchi University

Yun Jeong Choi

University of Tokyo

Kohta Mori

Department of Economics, Yale University

Yasuyuki Sawada

University of Tokyo

Saki Sugano

Graduate School of Economics, University of Tokyo

July 2009

CIRJE Discussion Papers can be downloaded without charge from:

http://www.e.u-tokyo.ac.jp/cirje/research/03research02dp.html

Discussion Papers are a series of manuscripts in their draft form. They are not intended for circulation or distribution except as indicated by the author. For that reason Discussion Papers may not be reproduced or distributed without the written consent of the author. 


\title{
Socio-Economic Studies on Suicide:
}

$\begin{array}{ccc} & \text { A Survey } & \\ & & \\ \text { Joe Chen* } & \text { Yun Jeong Choi† } & \text { Kohta Mori }{ }^{*} \\ \text { Department of Public Finance } & \text { Faculty of Economics } & \text { Department of Economics } \\ \text { National Chengchi University } & \text { University of Tokyo } & \text { Yale University } \\ \text { joe@nccu.edu.tw } & \text { yun@e.u-tokyo.ac.jp } & \text { kota.mori@yale.edu }\end{array}$

\author{
Yasuyuki Sawada \\ Faculty of Economics \\ University of Tokyo \\ sawada@e.u-tokyo.ac.jp
}

\author{
Yun Jeong Choi \\ Faculty of Economics \\ yun@e.u-tokyo.ac.jp
}

\author{
Saki Sugano** \\ Graduate School of Economics \\ University of Tokyo \\ ee097017@mail.ecc.u-tokyo.ac.jp
}

June 32009

\begin{abstract}
In this article, we review economic theories and empirical studies on the socioeconomic aspects of suicide. Through our survey, we would like to emphasize the importance of studying suicide by employing a "rational" approach that complements the medical perspective on suicide, which assumes suicide to be the result of "irrational" behavior arising from mental illnesses such as depression and other psychiatric disorders. We first introduce major economic theories of suicide, followed by a summary of a variety of empirical studies from the socioeconomic perspective. We then discuss the recent developments in economic studies on suicide, on the basis of the authors' ongoing project on suicide. In the concluding section, we point out some issues for further studies.
\end{abstract}

Keywords: Suicide, Socio-Economic Studies on Suicide

\footnotetext{
* J. Chen, Department of Public Finance, National Chengchi University, 64, Sec. 2, ZhiNan Rd., Wenshan District, Taipei 11605, Taiwan; e-mail: joe@nccu.edu.tw.

† Y. J. Choi, Faculty of Economics, University of Tokyo, 7-3-1 Hongo, Bunkyo-ku, Tokyo 113-0033, Japan; e-mail: yun@e.u-tokyo.ac.jp.

$\ddagger$ K. Mori, Department of Economics, Yale University, PO Box 208268, New Haven, CT 06520-8268, USA; e-mail: kota.mori@yale.edu.

$\S$ Y. Sawada, Faculty of Economics, University of Tokyo, 7-3-1 Hongo, Bunkyo-ku, Tokyo 113-0033, Japan; e-mail: sawada@e.u-tokyo.ac.jp.

** S. Sugano, Graduate School of Economics, University of Tokyo, 7-3-1 Hongo, Bunkyo-ku, Tokyo 113-0033, Japan; e-mail: ee097017@mail.ecc.u-tokyo.ac.jp.
} 


\section{Introduction}

Approximately 3,000 people commit suicide every day, and every 30 seconds, one suicide-related death is reported. Moreover, in the last 45 years, the suicide rate has increased by $60 \%$ worldwide (WHO, 2007). Apparently, suicide is one of the most vexing issues in all societies. Many medical professionals consider suicide to be the result of depression and other psychiatric disorders (Mann et al., 2005). In this line of reasoning, deliberately killing oneself is an irrational act resulting from mental illness. Doctors and psychologists look into the risk factors and causes of mental illnesses to explain suicidal behavior and to develop strategies and interventions for the prevention of suicidal acts (p. 8, in Maskill et al., 2005). However, any casual observer would argue that some suicides are well-motivated and "rational" in the economic sense and otherwise.

In this study, we review economic theories and empirical studies on suicide. Through our survey, we would like to emphasize the importance of studying suicides by employing a "rational" approach that complements the medical perspective on suicides. Psychological consultation and medical attention can neither resolve certain underlying motivations for suicide, such as unemployment, income insecurity, or financial stress, nor offer comprehensive social security solutions. Once people are willing to recognize that some suicides are rationalizable, studies can be conducted to ascertain the different incentives for suicides. We believe that this would help identify the resources necessary for the development and implementation of effective measures of suicide prevention, as warranted by the seriousness of the current situation.

There is abundant anecdotal evidence suggesting that suicides can be induced by government policy or private contract incentives. For example, the Indian Government's compensation for bereaved families appears to have an impact on the suicide rate (The Economist, June 21, 2007; The Hindu, April 15, 2008). With respect to private contracts, life insurance policies pay out death benefits to the beneficiaries of suicide victims only if the suicide was committed after the suicide exemption period. ${ }^{1}$ Such contracts serve as incentives for suicide for those who are truly desperate (Amamiya, 2002; Toyokawa and Shirouzu, 1998). ${ }^{2}$ One media report stated that from 1995 to 2005, a major Japanese life insurance company's payments increased by $50 \%$ due to suicides, and $10 \%$ of their total insurance payments were made to the beneficiaries of suicide victims in 2005 (Mainichi Shinbun, October, 4, 2005).3 Looking back at Japanese history, even some of the heavily ritualized suicides can be explained by economic incentives. For example, seppuku (stomach-cutting), a form of ritual suicide by self-disembowelment, was originally reserved for the samurai and the nobility classes in feudal Japan. However, many Japanese considered seppuku an honorable way of ending their lives. Mitford (1871) in Appendix A of his book Tales of Old Japan wrote:

"If the offence was heinous, such as would involve the ruin of the whole family, [after committing seppuku] by the clemency of the Tycoon, half the property might be confiscated, and half returned 
to the heir; if the offence was trivial, the property was inherited intact by the heir, and the family did not suffer.

In all cases where the criminal disembowels himself of his own accord without condemnation and without investigation, inasmuch as he is no longer able to defend himself, the offence is considered as non-proven, and the property is not confiscated."

As early as in 1897, Émile Durkheim proposed a sociological theory of suicide in Le Suicide. He explains suicide as a product of social conditions. Individuals have a certain level of attachment to their society through social norms and rules. An excess of "social integration" and "social regulation," considered by Durkheim as the two main sociological forces driving suicides, may result in increased suicide rates. Following him, many sociological studies emerged to support or negate his theory (Edwin, 2001). Economists, on the other hand, explain suicide as an individual decision. This approach considers that utility maximizing agents, confronting their own environments, choose to commit suicide when it appears to be the most preferable alternative. Although the economic approach to suicide developed much later, the pioneering work of Hamermesh and Soss (1974) provided a framework that generated numerous follow-up theories and empirical works to explain suicides.

The rest of the paper is organized as follows. In Section 2, we introduce major economic theories of suicide. Section 3 summarizes a variety of empirical studies from the socioeconomic perspective (Tables 1 and 2). Section 4 discusses some recent developments in economic studies on suicide, on the basis of the authors' ongoing project on suicide. In Section 5, as a conclusion, we point out some issues for further studies.

\section{Economic Theories of Suicide}

This section introduces major economic theories of suicide. The topics discussed include the utility maximization framework and the real option approach in explaining suicides. We also discuss suicide attempts from a strategic perspective. Further, we introduce contagion theory with the idea that suicide is an "epidemic." However, as of now, no theoretical study has applied the evolutionary game theory on contagion and social learning to explain suicides. Finally, we briefly discuss studies of suicide behavior under different access means and instruments.

\subsection{Suicide in the Utility Maximization Framework}

Hamermesh and Soss' (1974) economic theory of suicide was the first study to apply the utility maximization framework to suicide. In their framework, an agent chooses to commit suicide when his or 
her discounted lifetime utility falls below a certain threshold. Two main results emerged from their model. First, since an agent's utility increases with income, an increase in the permanent income reduces suicide. Second, since expected lifetime utility decreases as age increases, other things being equal, suicide increases monotonically with age.

However, Cutler et al. (2000) point out that in general, data do not support Hamermesh and Soss' second result. Koo and Cox (2008) extended Hamermesh and Soss' basic framework to include human capital as another main determinant of expected utility. In their model, human capital depreciates during spells of unemployment due to the lack of continuous job training. This implies that unemployment increases suicide rates by lowering not only the current income level but also future income expectations through human capital depreciation. Further, their model predicts that the effect of unemployment on suicide varies across age groups. The middle-aged group suffers the most when unemployed because they tend to take longer to adjust to new labor market conditions; hence, the depreciation in human capital is most severe in this group. This difference in the rate of human capital depreciation results in a non-monotonic relation between suicide rate and age, which Hamermesh and Soss (1974) fail to explain.

On the other hand, Dixit and Pindyck (1994, p. 24-25) approached the suicide issue from the real option perspective in which the "delay" of the decision to commit suicide is explicitly considered. Under conditions of irreversibility and uncertainty, an investor may have the option to hold the investment for a while and waiting to see what will happen in the future. Dixit and Pindyck argued that people thinking of committing suicide also have a similar choice to make. Indeed, suicide is an ultimate irreversible action. The prospect of a better tomorrow can convince a person who is seriously contemplating suicide to postpone the act. Hence, when it comes to making the decision to commit suicide, there is an "option value" of staying alive and waiting to see if the situation will improve.

Applying Dixit and Pindyck's idea, Cutler et al. (2000) introduced a three-stage dynamic optimization model with uncertainty, in which the agent is endowed with the suicide option in each stage. They explained the increase in youth suicide rates in the United States by showing that in cases of hyperbolic discounting and random-walk uncertainty, suicide rate changes non-monotonically with age. Meanwhile, Miao and Wang (2007) applied the real option approach and used Knightian uncertainty to explain youth suicides. They found that the option value is smaller with a higher level of Knightian uncertainty, and a risk-averse individual exercises the option to commit suicide earlier than an expected utility maximizer. Moreover, they argued that the option value of staying alive is low among young people due to high (Knightian) uncertainty, and hence, other things being equal, these young people are more likely to commit suicide. This suggests that the key to prevent youth suicides is to lower the level of Knightian uncertainty through measures such as making counseling services easily accessible to the youth.

Finally, Suzuki (2008) conducts comparative statics to understand how different parameters of income distribution alter the wage threshold below which an individual commits suicide. In his model, the 
mean of future income negatively affects the threshold level. Nonetheless, the effect of the variance of income distribution on suicide is a priori, undetermined. Although an increase in the variance of income distribution reduces the expected utility of risk-adverse individuals, it also creates a greater option value to postpone suicide decisions. However, he finds that the propensity to commit suicide increases monotonically with the variance of income, that is, the former effect dominates.

\subsection{Suicide Attempts}

Although most theoretical studies consider fatal suicides, that is, suicides that resulted in death, it is not uncommon, in practice, to observe that the methods used in some suicide cases are not lethal and unlikely to result in death. According to Petronis et al. (1990), for every suicide that results in death, there are approximately 20 suicide attempts. ${ }^{4}$ In order to prevent suicides, suicide attempts or self-harming behavior that does not result in death should not be overlooked.

Rosenthal (1993) explains non-fatal suicide attempts as signals of needs for help. He provided a game theoretic model similar to the signaling game in labor markets. Individuals confronted with bad situations need help, but those who can offer helps cannot identify the people who are really in need of help. Consequently, an individual faced with a bad situation may attempt suicide in an effort to signal that he or she really needs help. The possibility of the individual dying makes the signal credible, and hence, the suicide attempt works as signaling. Cutler et al. (2001) examines a different setup where suicide brings disutility for those who can help and prevent it from happening. For example, a child's suicide attempt results in medical costs to the parents as well as feelings of guilt and embarrassment at their child having attempted suicide. Therefore, they argue that even if it is not credible enough, a suicide attempt by a child results in the parents allocating more resources to the child.

Marcotte (2003), on the other hand, considers suicide attempts using the framework of Hamermesh and Soss (1974). Given that suicide attempts are credible signals for help, they bring in more resources and increase the income for survivors. In this sense, suicide attempts are considered as rational risk-taking behavior to obtain expost income increase. However, the model does not explicitly spell out why and how income increases after a suicide attempt.

\subsection{Contagion Theory}

Suicide contagion is a social phenomenon where one suicide precipitates suicide attempts by other people. This has been an important subject of study for centuries. ${ }^{5}$ Although it is difficult, unless pre-announced or a will is found, to determine whether a suicide was influenced by an earlier one, in practice, a cluster of suicides within a short period of time is often regarded as suicide contagion or a suicide "epidemic."' It is for this reason that the World Health Organization (2000) issued media guidelines on 
reporting suicide news. Despite the importance of this issue, there has been no economic theory explaining how and why suicides can be contagious.

Cutler et al. (2001) presented a story explaining suicide contagion but no model was constructed. They stated that when an individual commits suicide, the group to which he or she belonged experiences much grief and stress, and this may precipitate other suicides. Moreover, when a particular suicide becomes widely known, similar suicides or attempted suicides, in terms of the means used or otherwise, draw disproportionately more attention from the community, thus prompting copycat behavior.

From the theoretical perspective, the grief-and-stress story can be modeled using Hamermesh and Soss' framework while taking into account some negative externality of suicides. For suicide prevention, it is important to identify which cases of suicides may prompt similar acts. With respect to the modeling of copycat suicides, the evolutionary game theory on contagion and social learning can be quite valuable as a potential theoretical framework.

\subsection{Accessibility and Instrumentality}

In 2003, carbon monoxide poisoning as a means to commit suicide became well-known through the internet chat rooms and news reports in Japan. That year, the number of suicides hit a record high of 34,427 , and carbon monoxide suicide is considered to have contributed a great deal to this incidence of suicide (Suicide Investigation Team, 2008))7. Five years later, in 2008, information on creating hydrogen sulfide gas, which can be used to commit suicide, by mixing ordinary household cleaning products spread through online bulletin boards. Many experts in Japan call for policies to limit people's access to lethal means and control the spread of such information. The Office of Intelligence and Analysis of the U.S. Homeland Security and the Los Angeles Joint Regional Intelligence Center even produced a note to alert people to the potential hazards posed by hydrogen sulfide and the potential of using easily produced hydrogen sulfide as a chemical weapon in a terrorist attack (New York State Office of Homeland Security, September 26, 2008). According to the note, during the first 6 months of 2008 , more than 500 people in Japan killed themselves by inhaling hydrogen sulfide.

On the one hand, from a theoretical perspective, easy access to lethal means lowers the costs of suicide which would result in the increase of the number of suicides. Despite this clear implication, there has been no published economic study establishing this link. Clearly, a lack of individual level data is the main constraint. There are, however, quite a few psychological and public health studies that provide compelling evidence (Brent et al., 1988, 1991, 2001; Kellerman et al. 1991; Loftin et al., 1991; Kreitman, 1976). ${ }^{8}$ For future economic studies of suicide, exploring quasi-experiments such as U.S. and Canadian gun control regulations (Sommers, 1984; Carrington and Moyer, 1994) can offer new insights into this issue. On the other hand, some hypothesize that limiting one particular means of committing suicides only drives 
people to use different means and hence, does not really prevent suicide. ${ }^{9}$ In conclusion, the discrepancy in views and conflicting evidence calls for further studies.

\section{Empirical Perspectives}

This section reviews a variety of empirical works on suicide. Tables 1 and 2 summarize the literature. Since microdata on decisions to commit suicide are rarely available, most existing empirical studies employ aggregated data at the country, regional, or group level. Typically, using the regression method, empirical work has attempted to explain the relationship between socioeconomic factors as independent variables and suicide as the dependent variable. As shown in Table 1, most studies use suicide rate as the dependent variable. There are several types of suicide rates: total suicide rate (crude or age-standardized) ${ }^{10}$ gender-grouped suicide rate, age-grouped suicide rate, ${ }^{11}$ and the suicide rate of different regions. ${ }^{12}$ Some studies use the natural $\log$ of suicide rate while others use the suicide rate per 100,000 people. ${ }^{13}$

Various kinds of socioeconomic variables are used as independent variables (Table 2). However, the empirical results are not necessarily robust; they have mostly shown mixed results on the relationships between dependent and independent variables (Table 2). This may be due to the use of a different set of variables or different data and methodology.

In the following sub-sections, we discuss the existing findings on some important commonly used socioeconomic variables such as income and wealth, labor market variables, demography and household variables, health variables, and cultural factors.

\subsection{Income Level, Growth, and Heterogeneities}

\subsubsection{Income}

According to the permanent income hypothesis (Hamermesh and Soss, 1974), an individual decides to commit suicide when his or her discounted expected lifetime utility falls below a certain threshold. Therefore, theoretically speaking, higher income should be associated with higher utility, thus lowering the probability of committing suicide. Moreover, higher income is associated with higher standards of living and greater satisfaction with life, since more resources are available with which to cope with life's stressful events and circumstances (Burr et al., 1994). In practice, most papers use the real GDP per capita, per capita real income, economic growth, average growth rate of real income, and/or median family income. These variables capture the average economic characteristics of the observed group. However, since the data are not individual but country or group average data, the direct causality between an individual 
economic situation and an individual decision to commit suicide are not necessarily explained. Nonetheless, most studies indeed find that people with low income or countries with low GDP per capita have higher suicide rates. (Chen et al., 2008, 2009a; Chuang, 2003; Cutler et al., 2000; Daly and Wilson, 2006; Faupel et al., 1987; Helliwell, 2007; Huaung, 1996; Kimenyi and Shughart, 1986; Klick and Markowitz, 2003; Minoiu and Rodríguez, 2008; Rodríguez, 2006). This result, however, is not necessarily robust.

Some studies show a positive relationship between income and suicide rate, and use this as evidence supporting Durkheim's (1897) theory that poorer people may resign themselves to their economic situation and passively accept their lives (Burr et al., 1994; Jungeilges and Kirchgassner, 2002; Freeman, 1998; Lester, 1995; Rodríguez, 2005; Simpson and Conklin, 1989); thus, this coping mechanism may reduce the probability of suicidal behavior (Burr et al., 1994). Other studies support Easterlin's hypothesis (1974) that economic affluence is unrelated to happiness or general welfare (Blanchflower and Osward, 2004). It is yet possible that this positive relationship was due to limited data coverage or use of empirical methods (Burr et al., 1994; Lester, 1995; Jungeilges and Kirchgassner, 2002; Rodríguez, 2005). The other explanation is based on omitted variable bias. Burr et al. (1997) and Freeman (1998) note that without the presence of an income dispersion variable, the income variable may have captured the effect of income inequality, and resulted in this positive association. Moreover, Jungeilges and Kirchgassner (2002) argue that the negative association of the income variable with the suicide rate in many other studies mainly reflects business cycle conditions.

Finally, some studies point out that the impact of income can be asymmetric across age-gender groups. Chen et al. (2008) show that while income is negatively associated with suicide rate across all age-gender groups, its impact is more significant in males between 45-64 years of age and females over 65 years old. Huaung (1996) and Rodríguez (2006) show the significance of income for females while Neumayer (2003) and Minoiu and Rodríguez (2008) show its significance only for males. The impact of income may also differ across regions or environments. Faupel et al. (1987) indicate that the effect of median family income on suicide rate is significantly negative, especially in the most urban and medium urban counties of the United States but not in the least urban counties.

\subsubsection{Income Inequality}

In addition to aggregated income or average income, heterogeneities in income also affect decisions to commit suicide. In fact, most researchers agree that income inequality leads to higher suicide rates (Chen et al., 2008). Relatively deprived individuals may experience more stress, leading to poor health conditions and ending directly or indirectly, through alcohol abuse or smoking, in suicide (Rodríguez, 2005; Stack, 2000; Wilkinson, 1997).

As a measure of income inequality, most studies use the Gini index as a proxy for income inequality (Rodríguez, 2005, 2006; Chen et al., 2008, 2009a; Faupel et al., 1987; Freeman, 1998). Some 
studies use other variables; for example, Minoiu and Rodríguez (2008) use the change in annual poverty rates for families with children in addition to the annual change in per capita income as a proxy for living standards, and Dale et al. (2006) use interpercentile income ratios to take into account the effect of relative income and absolute income.

Despite the theoretically clear prediction, the empirical evidence is mixed. Some studies (Faupel et al., 1987; Daly and Wilson, 2006; Chen et al., 2008; Minoiu and Rodríguez, 2008) find a significantly positive relationship between income inequality and suicide rate, while others fail to find a statistically significant relationship (Neumayer, 2004; Rodríguez, 2005).

\subsubsection{Economic Growth and Recession}

So far, we have focused on levels of income, average income, and income disparities. Changes in these levels should also affect suicide decisions. If economic growth brings better occupational and financial prospects for the future, people will be hopeful and the probability of committing suicide may decrease. On the other hand, rapid economic growth may be accompanied with rapid social structural change, causing problems for older people in particular. Such growth-driven social instabilities may increase suicide.

While many researchers have found a significant relationship between economic growth and suicide rate, others have not (Chen et al., 2008, 2009a; Jungeilges and Kirchgassner, 2002; Neumayer, 2003; Rodríguez, 2005; Stack, 1998). Rodríguez (2005) shows that economic growth has a significantly negative impact on suicide rate. Viren (2005), using annual Finnish data from 1878 to 1999, shows that suicide rates increase when income growth prospects deteriorate and vice versa. The results differ across age-gender group suicide rates with OECD countries panel data from 1980 to 2003 (Chen et al., 2008, 2009a). ${ }^{14}$

Financial stress during economic crises is often considered as one of the main factors of suicides. Indeed, Watanabe et al. (2006) use Japanese panel data and show that both personal bankruptcy and firm bankruptcy have a significantly positive effect on male and female suicide rates. Their results are consistent with the hypothesis that economic crisis is associated with high suicide rate.

\subsubsection{Education as an Important Determinant of Income}

Education level is regarded as one of the important determinants of income. A high level of education is considered to prevent people from attempting suicide because high education leads to better jobs and higher income. In this sense, education has an indirect relationship with suicide, through socioeconomic factors such as employment status or income inequality. If education leads to higher satisfaction in life, it is directly associated with lower suicide rate. On the other hand, a high level of education may be associated with a higher suicide rate due to lower adherence to religious beliefs and greater tendency toward materialism and individualism, which may weaken the bond between individuals 
and society. This is in line with Durkheim's social integration theory. Moreover, people with higher education may experience higher levels of frustration and stress because of increasing academic competition among students and coworkers; thus, higher education could be associated with a higher suicide rate. Using cross-county data of 3,077 counties in the United States, Barnes (1975) shows that the coefficient of the median years of schooling by people aged 25 years and above is significantly positive. Suicide risk is the highest in the gender-age-race-county group with a higher number of high school-educated individuals but falls with increases in the number of college-educated individuals. Faupel et al. (1987) show that the median education level in each county in the United States had a significantly positive effect on suicide rates in the middle urban and most urban counties but not in the least urban counties. Meanwhile, Klick and Markowitz (2003) show that the states in which higher percentages of the population have college degrees have low suicide rates.

\subsection{Labor Market}

\subsubsection{Unemployment}

Unemployment can be considered as a predictor of future income; it signals a decrease in permanent income. Hence, according to Hamermesh and Soss' (1974) framework, the rising unemployment rate should lead to an increase in the incidence of suicide and suicide attempts. Moreover, unemployment may be associated with mental and/or physical illness, which could lead to suicide. Many studies find that a high unemployment rate tends to be associated with a high suicide rate (Brainerd, 2001; Burr et al., 1994; Chen et al., 2008, 2009a; Chuang and Huang, 2003; Daly, 2006; Faupel et al., 1987; Freeman,1998; Huaung, 1996; Kimenyi and Shughart, 1986; Klick and Markowitz, 2003; Koo and Cox, 2008; Lester, 1995; Mäkinen, 1997; Minoiu and Rodríguez, 2008; Neumayer, 2003; Rodríguez, 2005; Watanabe et al., 2006).

\subsubsection{Female Labor Force Participation}

The relationship between gender-specific characteristics of employment and suicide has been discussed in the literature. Most studies show that high male and female suicide rates are associated with high female labor participation rates (Chen et al., 2008; Cutler et al., 2000; Koo and Cox, 2008; Mäkinen, 1997; Klick and Markowitz, 2003; Neumayer, 2003; Rodríguez, 2005, 2006; Stack, 1998). However, some studies show that increasing female labor participation results in lower suicide rates (Burr et al., 2004; Faupel et al., 1987). High suicide rates associated with high female labor participation rates has been argued to be the result of the "role conflict" and weakening family ties and social integration. Meanwhile, low suicide rates associated with high female labor participation rates may be explained by "role accumulation," where the benefits of working outweigh the costs, either through financial benefits or social integration. Therefore, the net effect of female labor participation is not clear. 


\subsection{Demography and Household}

\subsubsection{Divorce Rate and Marriage Rate}

According to Durkheim's theory, divorce reduces social integration and family ties. Divorce can cause shame, stress, and other mental pain, which may result in risky behavior like suicide. Therefore, higher divorce rates are likely to be associated with higher suicide rates (Burr et al., 1994; Chuang Huang, 2003; Faupel et al., 1987; Freeman, 1998; Helliwell, 2007; Kimenyi and Shughart, 1986; Lester, 1995; Mäkinen, 1997; Minoiu and Rodríguez, 2008; Neumayer, 2003). Some papers show that the male suicide rate is more sensitive to divorce than the female suicide rate (Chen et al., 2008; Koo and Cox, 2008; Neumayer, 2003; Rodríguez, 2005; Watanabe et al., 2006). Men may be more susceptible to mental pain from divorce. Perhaps marriage has greater benefits for men than for women, in which case, the loss of the benefits after divorce may affect men more than they would affect women. On the other hand, if marriage serves to overregulate the lives of women, increasing divorce rates may be the result of financial independence for women, laws favoring women in financial settlements, women's search for identity and freedom, etc. Thus, divorce rates may be associated with lower female suicide rates.

\subsubsection{Birth Rate}

High birth rate may reduce the risk of suicide by promoting social or domestic integration (Durkheim, 1897; Faupel et al., 1987; Koo and Cox, 2008; Mäkinen, 1997; Neumayer, 2003; Rodríguez, 2005). However, some studies show that birth rate has a positive impact or no impact on suicide rates (Chen et al., 2008, 2009a; Lester, 1995). One possible explanation is that childcare may bring too much strain or be too much of an economic burden, thus leading to suicidal behavior. Another possibility is the effect of certain omitted variables.

\subsubsection{Social Isolation and Household Size}

According to Durkheim's theory, social isolation, disintegration, and disconnectedness lead to suicide. As a proxy for social isolation, variables such as household size and proportion of one-person households are used.

Neumayer (2003) shows that household size has a significantly negative effect on female suicide rates and an insignificantly negative effect on male suicide rates. Burr et al. (1994) use the proportion of one-person households in a metropolitan area as the indicator of social isolation and shows a positive relationship between the proportion of one-person households and suicide rates. Daly and Wilson (2006) show that as per U.S. aggregate data, the share of married people had a significantly negative impact on suicide rates in both 1990 and 2000, whereas that of single/never married people had a significantly positive impact on suicide rates in the individual level data. Faupel et al. (1987) show that the percentage of people living alone has the most negative effect on suicide rates in the most urban counties as compared to the 
middle urban or least urban counties. Chuang and Huang (2003) use the proportion of widowed population in each region in Taiwan as the indicator of social isolation and shows that its impact is significantly negative on the total suicide and female suicide rates but not on the male suicide rate. It is surprising that a region with a greater proportion of widows has a significantly lower suicide rate. The researchers argue that the existing widowed population may include those who have been widowers for some time and have built enough resilience; therefore, they are at less risk for suicidal behavior than widowers who have just lost their husbands. Daly and Wilson (2006) also find that the share of widowed people had a negative relationship with suicide rate in U.S. counties in 1990 and 2000; however, they provide no explanation for it.

\subsubsection{Population}

Population density or population growth is used as a proxy for modernization or urbanization. Durkheim's theory predicts that the process of modernization or economic development may reduce the level of social integration and thus, increase suicide rates.

Burr et al. (1994) measure population concentration (density) as the number of persons per square mile, logarithmically transformed to correct for skewed data in 294 metropolitan areas in the U.S. in 1980. They show that although population density has a negative effect on suicide rate, it is statistically insignificant when membership to the Catholic Church is included as an independent variable and statistically significant when membership to the Protestant Church or total church is included as an independent variable. Minoiu and Rodríguez (2008) show that population density reduces total suicide rate. Zhang (1998) uses population growth rate as a measurement of urbanization and shows that it had a significantly negative effect on the suicide rates in 31 developing countries as well as 29 developed countries during the 1980-1986 period.

On the other hand, many studies focus on population heterogeneity. The share of minority and indigenous people is said to have a positive relationship with suicide rate. Rapid colonization, cultural alienation, loss of identity, and social disintegration lead to anomie, low self-esteem, despair, and deprivation. Therefore, communities with higher ethnic heterogeneity are considered to have higher suicide rates. Neumayer (2003) shows that ethnic heterogeneity has a significantly positive effect on male and female suicide rates. However, the suicide rate among blacks has been observed to be lower than that among whites. Burr et al. (1994) study the proportion of two of the largest minority groups, black and Hispanic, in the U.S. The impact of the black population size on the suicide rate in 294 metropolitan areas in the U.S. was statistically insignificant in 1980. Faupel et al. (1987) also use the variable of black population as a cultural and an economic indicator of differences in society. Their results show that the black population share contributes to a decline in the suicide rate. Finally, Daly and Wilson (2006) conclude that whites have a higher suicide risk than do other races in the U.S., that is, non-blacks and blacks. 


\subsubsection{Migration}

Migration may reduce the level of social integration because it involves the separation of families, friends, and co-workers and thus, the weakening of community ties. People migrating to another country experience more stress due to cultural differences and perhaps, a language barrier. As migrants are usually a minority in society, they face the same problems that minorities do, such as loss of identity, higher unemployment rate, and poverty, and therefore, may have higher suicide rates.

Faupel et al. (1987) use net migration change as a proxy for integration in addition to the variable of living alone. Net migration change has a positive relationship with suicide rate in all U.S. counties. After dividing the counties into three levels of urbanization, the coefficients of migration change on suicide rate are significantly positive in the middle and most urban counties but not in the least urban ones.

Lester (1995), using 48 continental states of the U.S., shows that social characteristics such as longitudes, marriage rate, divorce rate, and median family income predict suicide rates only for those born in non-contiguous states and abroad but not for those born in-state or in contiguous states. This result supports the explanation of selective migration, which suggests that suicidal people move to certain regions more often than they do to other regions, and that states with high migration and/or immigration may have higher suicide rates because of the higher suicide risks of those migrants/immigrants. Chuang and Huang (2003) use the proportion of aboriginal population and in-migration rate as indices of the minority group in Taiwan. The proportion of aboriginal population has a positive effect on suicide rates and a greater impact on male suicide rate than on female suicide rate. On the contrary, larger in-migration population is associated with lower suicide rates. They argue that it has served as a proxy for the quality of life because the regions with high in-migration rates have many desirable characteristics that attract the influx of migrants.

\subsubsection{Age and Gender}

Various socioeconomic factors affect suicidal behavior, and their impacts differ across age groups. Old people are considered to be exposed to a higher suicide risk. They may experience health anxiety, economic anxiety, and loneliness from living alone or after the death of a close person. This is consistent with Durkheim's theory that social integration tends to decline with age. Therefore, suicide rates are higher among old people than among other generations.

Young people, on the other hand, are vulnerable to family problems like parental marital disharmony, separation, divorce, violence, and abuse. They may also experience unemployment fears, perhaps due to lower educational or socioeconomic status, which leads to despair about the future.

Mäkinen (1997) uses the share of people under 15 years old and that of people over 65 years old. The share of young people had a significantly negative correlation with the suicide rate in 1977-1979 but a significantly positive correlation with changes in the suicide rates from 1977 to 1979 and 1988 to 1990 . The share of the 
population over 65 years old had a positive but insignificant correlation with the suicide rate. Simpson and Conklin (1989) show that countries with a high percentage of people over 65 years of age tend to have high suicide rates. However, Faupel et al. (1987) show that in most urban counties, the median age is negatively associated with suicide rate. Meanwhile, Cutler et al. (2000) find that the increased share of youths living in a home with a divorced parent is the most important factor explaining the rise of youth suicide.

\subsubsection{Gender}

There is a significant gap between male and female suicide rates. A possible explanation is given by gender roles or identity. Men are usually expected to be strong and successful and therefore, sensitive to perceived loss or failure. Women, on the other hand, tend to express their thoughts and feelings, have more extensive social networks in which to do so, lower alcohol abuse, and less access to lethal suicide methods.

Chuang and Huang (2003) examine gender gap and show that from 1983 to 2001, in 23 cities and counties in Taiwan, the annual average male and female suicide rates were 16.82 and 10.52, respectively. Daly and Wilson (2006) show that men were significantly more likely to commit suicide than women among all age groups in the U.S. in 1990 and 2000. Male suicide rates vary slightly across age groups, whereas suicide rates for women generally increase with age. Ford and Kaserman (2000) use cross sectional observations of dialysis patients in the U.S. (individual data) and show that although it cannot be generalized, the probability that a dialysis patient will commit suicide is lower for male patients and increases with the age of patients. Helliwell (2007) says that the male suicide rate per 100,000 people is typically between three and four times the female suicide rate in 117 country-waves. Lewis and Sloggett (1998) show that unemployment is the most important factor affecting suicide among working age people. The odds ratio of committing suicide is significantly lower for women, that is, 0.46 , than it is for men, that is, 1 . On the other hand, Cutler et al. (2000) show that, among young people, more males than females successfully commit suicide, but more femlaes attempt suicide.

\subsubsection{Cohort Effect}

A cohort is a group of people of approximately the same age, born in the same year or series of years. Individuals in the same cohort share the same experiences such as wars and economic fluctuation, leading to cohort-specific behavior. For example, people who have lived through a war might experience greater ideological turmoil than people in other cohorts that have not. Further, relative cohort size may also shape the behavior and characteristics of people in a cohort. For example, people in the post-war or baby-boom cohort have a larger relative cohort size and may have experienced greater competition among them.

Gunnell et al. (2003) assess whether cohort effects underlie the changes in suicide rates in England 
and Wales from 1950 to 1999. They show that succeeding generations of males born in the post-war years show increasing rates of suicide at all ages, which is also observed for some industrialized countries such as Belgium (Moens et al., 1987), Canada (Solomon and Hellon, 1980), Italy (La Vecchia et al., 1986), New Zealand (Skegg and Cox, 1991), Spain (Granizo et al., 1996), Sweden (Allebeck et al., 1996), and the United States (Murphy and Wetzel, 1980).

\subsection{Health}

\subsubsection{Alcohol Consumption}

Those who are deprived or depressive may have alcohol or smoking addictions and a high risk of committing suicide. Some research has found that individuals with higher alcohol consumption are likely to have higher suicide risks (Chen et al., 2008, 2009a; Neumayer, 2003; Rodríguez, 2005). As a proxy for alcohol consumption, Rodríguez $(2005,2006)$ uses aggregate alcohol sales in terms of pure liters of alcohol per year and per inhabitant, and shows that its coefficient on suicide rate is significantly positive, especially in male and female groups of 45-64 years old. Chen et al. (2008, 2009a) use sales data of pure alcohol in liters per individual over 15 years old. In Chen et al. (2008), the impact of alcohol consumption on Japan's suicide rate is positively associated with the male suicide rate, and the relationship between alcohol and suicide in Japan is noticeably different from that of other OECD countries. Using alcohol consumption in liters per capital, Neumayer (2003) shows that alcohol consumption is positively associated with male suicide rate but not with female suicide rate.

\subsubsection{Health Care}

As suicide is deeply related with mental health problems, there is much research on suicide that addresses health care. The hypothesis is that the level of health services provided by the government, which improves the health level of its population, is correlated with observed suicide rates. Access to health care may help save the lives of people attempting suicide. If health care services are less accessible, ill people may choose not to seek professional help. Further, these factors can capture people's perceptions of how generously the government spends on their well-being and whether this affects their satisfaction levels.

Kimenyi and Shughart (1986) use panel data from 1940 to 1980 and show that suicide rates decrease as the ratio of cost of health to CPI decreases. Yang and Lester (1993) regress suicide rates on the relative cost of health care for six age groups; $15-24,25-34,35-44,45-54,55-64$, and over 65; and show that they are significantly positive for the age groups of 15-24, 25-34, and 55-64 years old.

One tangible intervention would be the presence of accessible suicide prevention care. Chuang and Huang (2003) show that local suicide crisis-intervention agencies like Life-Line centers work to reduce the suicide rate. 


\subsection{Cultural Factors}

\subsubsection{Religion}

People with higher levels of religiosity or religious affiliation are generally thought to have a lower suicide risk because religion plays the role of an insulator. Certain religions are considered more effective than others in promoting social integration and preventing suicide. For example, Islam prohibits suicide and Catholicism considers it a mortal sin. Therefore, Islamic communities are thought to have lower suicide rates than others. In Durkheim's observation, Catholicism is more against suicide than Protestantism, which emphasizes the spirit of free inquiry and thus, leads to less regulation. Some find that countries or areas with high religiosity (Catholics, Protestants, and Muslims) tend to have lower suicide rates (Burr et al., 1994; Faupel et al., 1987; Helliwell, 2007; Simpson and Conklin, 1989).

Burr et al. (1994) use membership to the Catholic Church, Protestant Church, and total church in 1980 as measures of church-oriented religion in 294 metropolitan areas in the U.S and show a negative relationship between religion and suicide rate.

Faupel et al. (1987) examine the effect of Catholicism on suicide using U.S. county level data. The percentage of Catholics in U.S. counties has generally little predictive value in explaining suicide rates; however, they show that a higher share of Catholics is associated with lower suicide rates in the middle urban and most urban counties but not in the least urban ones. Moreover, the relationship between the Catholic percentage and suicide is strongest in the middle urban counties. They argue that middle urban counties may lack the extensive kinship relationships that are characteristic of more rural counties as well as the multiplicity of integrative voluntary organizations, which is characteristic of highly urbanized counties. Huaung (1996) shows that in 1990, the coefficient of the religion dummy for Catholicism or Islam (a country with over $85 \%$ of the population being Roman Catholic or Muslim is given by 1) was significantly negative on total suicide rates and male suicide rates in 48 countries. The strong condemnation by the Church or the Koran against suicide may reduce the national suicide rate. Simpson and Conklin (1989) use cross-country data of 71 countries and show that while both Christianity and Islam do not appear to reduce suicide rates, countries with a high Islamic population tend to have lower suicide rates even after controlling for economic, social, and demographic modernity. They explain that as Islam is a religion that binds its adherents to a strict code of conduct and calls for submission of the self to collective will, it may be a prophylactic against suicide.

\subsection{Other Factors}

\subsubsection{Homicide Rate}

There is a possible link between suicide and homicide. This idea originates from Ferri (1917) and Morselli (1882), who argue that suicide and homicide are two outlets for the same mental condition with the choice of outlet depending on social conditions. Kendell (1970) also hypothesized that suicide and 
homicide should be inversely related. Indeed, Henry and Short (1954) did find some supportive evidence of this negative relationship. However, it is also argued that acts of suicide and homicide tend to occur more frequently when a large percentage of people find it impossible to achieve social and personal goals, for example, in times of civil disorder or turmoil. Following this line of reasoning, suicide and homicide should move in the same direction. Supporting evidence was found by Mäkinen (1997) and Mckenna et al. (1997)

\subsubsection{Geographical and Climatic Conditions}

Geographical or seasonal conditions may affect suicide rates. Statistics show that in many countries, especially the less-industrialized ones, higher suicide rates are observed in spring, known as the "spring peak." Chew and Mccleary (1995) use cross-country data of 28 countries from the 1960s to the 1980s and show that countries with a large agricultural workforce have relatively high spring peaks and countries with a large industrial population have low spring peaks. Furthermore, they show that latitude, as a measure of the strength of bioclimatic influences, affects suicide seasonality only in the temperate zone. However, Helliwell (2007), using latitude as a measure of the exposure to sunlight, suggests otherwise. Using cross country data of 117 countries from the 1980s to the 1990s, he shows that higher latitude is associated with higher suicide rates. On the contrary, Neumayer (2003) finds that minimum hours of daily sunshine does not have a significant effect on suicide rates but shows that average temperature has a significantly positive effect on female suicide rates. Meanwhile, Lester (1995) shows that in the U.S., around the year 1960, longitude was positively associated with total suicide rates and suicide rates of those born out-of-state and in non-contiguous states. Finally, Minoiu and Rodríguez (2008) take the topographic aspect into account and use U.S. panel data of 47 states from 1982 to 1997 to show that mountain states such as Arizona, Colorado, Idaho, Montana, Nevada, New Mexico, Utah, and Wyoming have significantly higher suicide rates.

\subsubsection{Lifestyle}

Faupel et al. (1987) use the level of occupational diversity as a proxy for urbanization. Using 3,108 U.S. counties, they show a positive relationship between urbanization and suicide rates in the most urbanized counties, a negative relationship in the middle urbanized counties, and an insignificant relationship in the least urbanized counties. On the other hand, Cutler et al. (2000) use the changes in the percentage of farm population and urban population in 49 states in the U.S. from 1950 to 1990 as indices of urbanicity. Unlike the changes in the percentage of farm population, changes in the percentage of urban population have a significantly positive effect on the changes in total suicide rates.

\subsubsection{Civil Liberty and Quality of Government}

Jungeilges and Kirchgassner (2002) use a civil liberty index, which reflects the level of rights to 
freedom of expression and to fair trial, with cross-country data of 30 countries in 1975 and show that in general, the suicide rate is lower in free societies than in societies with a strong dictatorship. In addition, the civil liberty index lowers suicide rates among people aged 35 years and older, particularly men. This is probably due to the fact that in 1975, it was tough for women to pursue a career in politics as this would conflict with their roles as wife and mother. In accordance with the previous findings, Helliwell (2007) uses cross-country data of 117 countries from the 1980s to the 1990s and shows that the coefficients of trust and quality of government have a significantly negative effect on suicide rates; further, these effects increase with age and are stronger among men.

\section{Recent Developments in Economic Studies on Suicide}

This section points out some of the recent developments in economic studies on suicide. ${ }^{15}$

\subsection{Monetary Incentives}

Suicide induced by monetary incentives, while it has been disregarded in existing literature, are common. Even government policies can induce suicides through monetary transfers. For example, there has been an increase in the suicide rate in some states in India, probably due to the government policy of compensating bereaved families when breadwinners commit suicide (The Economist, June 21, 2007).16

Chen el al. (2008) points out life insurance payments as another potential link. Life insurance contracts provide monetary incentives to commit suicide as death benefits are paid out to beneficiaries if the suicide was committed after the suicide exemption period. In fact, Toyokawa and Shirouzu (1998) and Amamiya (2002) point out an increase in the number of suicides among life insurance policy holders immediately after the suicide exemption period. One media report stated that from 1995 to 2005, a major Japanese life insurance company's payments increased by 50\% due to suicides; further, in 2005 , $10 \%$ of the company's total insurance payments were towards suicide-related deaths (Mainichi Shinbun, October 4, 2005). These findings indicate that some suicides were induced by adverse selection and moral hazard under asymmetric information.

According to asymmetric information models, in the presence of substantial adverse selection and moral hazard, life insurance participants would have a higher suicide rate than non-participants. After Villeneuve (2000) pointed out that no economic research directly explored this potential link between suicide and life insurance, Tseng (2006) is the first economic study to investigate the link using mortality data from the Society of Actuaries (SOA). His results reveal that the suicide rate of the insured quadrupled after the 
suicide exemption period. However, contradictory to the prediction of asymmetric information models, his data show that the suicide rate of the general population was two to three times higher than that of the insured. ${ }^{17}$ Meanwhile, Chen et al. (2008) investigate the nexus between life insurance and suicide using OECD cross-country data from 1980 to 2002. Since unobserved factors such as risk types and preferences affect both life insurance participation and suicide, it is difficult to identify the causal effect of life insurance on suicide. The novelty of their analysis lies in the use of data on cross-country variations in the length of the suicide exemption period as the main identifying instrument for life insurance density. In fact, they found that a longer exemption period or no life insurance payment in cases of suicide is associated with a decrease in the purchase of life insurance policies. Since a short exemption period may induce self-selection of riskier types into life insurance contracts, the estimation result suggests the presence of adverse selection. After correcting for potential bias arising from omitted variables and endogeneity, they find a positive causal relationship from life insurance to suicide rate for a majority of observations. This suggests the presence of moral hazard in life insurance markets. ${ }^{18}$ However, one cannot rule out the possibility of a spurious relationship due to the nature of the highly reduced-form approach and the aggregate data used by them. Individual-level data can be used to test the existence of asymmetric information (Chiappori et al., 2006). To further distinguish between the effects of adverse selection and moral hazard on suicides, dynamic data on individual life insurance contracts may be needed (Abbring et al., 2003).

\subsection{Strong Social Stigma and Suicide}

Excess of social integration, as Durkheim (1897) points out, may increase suicide rates. Here we point out that private contracts which facilitate transactions based on social integration may backfire in highly integrated society, resulting in suicide.

The co-guarantor system is common in Japan. In particular, for small- and medium-borrowing without collateral, the co-guarantor contract is a standard practice used by creditors and borrowers to facilitate credit market transactions. Under this contract, a borrower is required to find a co-guarantor, usually a close family member or a very close friend, who is jointly liable for the full amount of debt. The Japanese co-guarantor system or joint liability contract is similar to the micro-credit program initiated by Dr. Muhammed Yunus of the Grameen Bank.

The group lending contract in micro-credit programs effectively makes the peers of a borrower the co-guarantors of his or her loan (Armendáriz de Aghion and Morduch, 2005). This joint liability arrangement mitigates adverse selection and moral hazard in credit markets through peer screening and monitoring mechanisms, respectively (Ghatak, 2000; Stiglitz, 1990). Furthermore, it weakens the incentives of strategic defaults through an informal enforcement mechanism or social collateral, as Besley and Coate 
(1995) call it. On the other hand, Besley (p. 2179, 1995) cites anthropologist Ardener's (1964) study where suicide may be the result of social stigma against those who are unable to pay the installments in rotating savings and credit associations (ROSCAs), suggesting the link between strong social stigma and suicides in private contacts. Chen el al. (2007) also point out that when the borrower fails to repay his debt, this informal enforcement mechanism may put too much pressure on him or her in the form of stigma, social penalty, or borrower's altruism, eventually pushing the borrower to commit suicide. Looking into the potential connection between the Japanese joint liability system and suicide, Chen el al. (2007) theorize that this borrowing system could result in suicidal acts by borrowers because of excessive pressure. They provide some empirical evidence to support their claim based on the joint Life-link and University of Tokyo survey on suicide victims. Indeed, as West (2003) suggests, many people in Japan seem to believe that committing suicide lessens the burden on family members, as opposed to having them live with a debtor.

\section{Concluding Remarks}

There is an emerging concern over the associated effect of the ongoing global financial crisis on suicide rates (Time, Oct 8, 2008). ${ }^{19}$ Given the empirical studies on the relationship between suicide and economic factors, this concern is well-founded. Moreover, the incidents in Japan suggest that the worst is yet to come.

Since the early 1990s, when Japan's "bubble economy” burst, the country has been suffering a slow and even negative growth accompanied by price deflation. Despite this, the suicide rate was not immediately affected. Although there was a slight increase in the male suicide rate, the female suicide rate showed a decreasing trend until 1997. However, things changed dramatically in 1998, when a 34.73\% increase in the number of suicides shocked the nation. Since then and for 11 years straight, more than 30,000 people, in a country with a population of 120 million, committed suicide every year. Chen et al. (2009b) estimate that there are approximately three million living family members in Japan who have lost a loved one to suicide, and the direct production loss of bereaved family members in 2006 alone was estimated at approximately 197 million USD. The government reports and media were quick to point out the domestic financial crisis brought about by the collapse of mega-banks in 1997 as one of the main reasons (Cabinet Office, Suicide White Paper, 2007). Nonetheless, we are anxious that this commonly mentioned link between the sudden jump in the number of suicides and economic hardship has not been rigorously studied. The collapse of mega-banks in 1997 in Japan is often referred to as a typical example of a "credit crunch" (Woo, 2003). Existing studies show that the negative impact of this credit crunch disproportionately damaged small firms, resulting in debt insolvencies and personal bankruptcies among many small business owners. As the data suggest, the number of applications for personal bankruptcies 
jumped from 43,545 in 1993 to 122,741 in 1999 (Sawada et al., 2007). There is no doubt that economic hardship and the mental burden of debt and personal bankruptcies contributed to this jump in the number of suicides. The research questions to be addressed are to what extent can Japan's credit crunch explain the abrupt increase in the number of suicides in 1998? Could other reasons such as the presence of adverse selection and moral hazard in government policies and private contracts have played a role in this increase? Before 1998, what has helped Japan to tame suicide rates despite the burst of bubble? What are the lessons learned in terms of suicide prevention from the lost decade in Japan that can help people under the current global crisis?

When studying suicide in Japan, an equally and perhaps more important question comes to mind. Despite some recovery in the economy in 2003 and 2004 and despite the numerous efforts made by the government and other organizations, the rate of suicide remains consistently high. ${ }^{20}$ Although this has never been researched or identified, there seems to be some sort of "inertia" at work behind the suicide numbers in Japan. Is this static pattern in the suicide numbers a phenomenon in Japan alone, or is it a universal phenomenon? In the case of the latter, what contributes to it? Can we construct a formal model of suicide epidemics that is able to explain the inertia using, for example, a social learning framework? Answers to these questions will contribute to the understanding of suicide and to the development of effective suicide prevention measures.

To conclude this short review, one common caveat of most existing empirical studies is the use of aggregate data. For example, a country with a high divorce rate may also have a high suicide rate, but it can well be the case that it is those who are married who commit suicide and not those who are divorced. Due to data limitation, most socioeconomic studies on suicide use aggregate level variables such as state-level data in the U.S., country level data of OECD countries, and so on. Another concern is the use of reduced form regression analysis. Although it is useful in identifying the correlation between socioeconomic variables and suicide rate, it is not necessarily sufficient for establishing a causal relationship. To uncover the motivation and incentives of suicides, individual or disaggregate data as well as more structural estimation are much needed.

\section{Acknowledgements}

This research was financially supported by the Research Center for the Relationship between Market Economy and Non-market Institutions (CEMANO), a 21st Century Center of Excellence (COE) Program of the Graduate School of Economics, University of Tokyo. 


\section{Notes}

1 A suicide exemption period (suicide provision or suicide clause) states that if the insured commits suicide within the period specified in the suicide clause of the life insurance contract, the death beneficiaries would not be paid any death benefits; however, after this period lapses, death by suicide is treated as death caused by any other reasons.

2 In response, the Japanese insurance companies had, since 2000, extended the suicide exemption period from the old industrial norm of 1 year to 2 years. It was further extended to 3 years from 2005.

3 Japan has been experiencing a suicide rash since the mid-1990s, amid a prolonged period of economic recession. The number of suicides, as released by the Japan National Police Agency, jumped by from 24,391 in 1997 to 32,863 in 1998, that is, by $34.73 \%$. Since then, more than 30,000 people have killed themselves each year.

4 The U.S. Federal Centers for Disease Control and Prevention (2001) estimate 17 suicide attempts for every fatal suicide. McIntosh (2008) estimates 816,000 annual attempts in the U.S. by using a 25:1 ratio (attempted to fatal suicide ratio).

5 One of the earliest stories is that of Goethe's novel Die Leiden des jungen Werther (The Sorrows of Young Werther), published in 1774, in which the hero shoots himself after an ill-fated love. Shortly after the book's publication, many young men used the same method to commit suicide. Two hundred years later, in 1974, sociologist David Phillips coined the term "the Werther effect" to describe imitative suicidal behavior transmitted via the mass media.

6 Using data from the New Zealand Health Statistics Services for 1988-1990, Gould et al. (1994) conclude that the clustering of attempted suicides among the youth is evidence of the contagion of suicidal behavior. Suicides of 8 young natives in an Algoma village of 200 within 1 year (Ward and Fox, 1977), suicides of 5 teenagers in a rural community in western Canada over 6 months, and the outbreak at Big Cove, New Brunswick, in 1992 (Royal Commission report) are examples of suicide from contagion (p. 50, Leenaars et al., 1998).

7 This YR 2003 suicide number is published by the Japan National Police Agency. It is slightly higher than that published by the Japan Ministry of Health, Labour and Welfare which is 32,109. Exactly how many of them were died due to carbon monoxide suicide is unknown, but the number of suicides by gas, under which carbon monoxide suicides are categorized, is 3,538. It increased from 1,514 in 2002 by 2,024 persons, an increase of 134 percent. During the same period, the overall suicide number increased by 2,160 people, an increase of 7 percent.

8 Kreitman (1976) showed that the suicide rate in Great Britain decreased dramatically with the decrease in the average carbon monoxide content of domestic gas. Beautrais (2001) pointed out that the removal of safety barriers from a known suicide site in Australia led to a substantial increase in the number of suicides by jumping from that site. Brent et al. (1988, 1991, 2001), Kellerman et al. (1991), and Loftin et al. (1991) showed that easy access to firearms or guns is positively associated with suicides.

9 Indeed, in Suriname, after the government banned the sale of undiluted acetic acid, there were fewer suicides by ingesting undiluted acetic acid. However, suicides by drinking other toxic substances increased (WHO, 1986). O'Carroll and Silverman (1994) pointed out the lack of evidence that the construction of barriers on a bridge in Washington D.C. causally resulted in an absolute reduction in 
the number of suicides. Reisch et al. (2007) suggested that the responses to barriers on bridges differ by gender. Their results for men revealed a trend of overdosing instead of jumping off a bridge in regions without suicide bridges; no method substitution was found for women.

10 The total suicide rate is used in Burr et al. (1994), Daly and Wilson (2006), Kimenyi and Shughart (1986), and Klick and Markowits (2008). The age-standardized suicide rate is used in Simpson (1989) and Chen et al. (2008).

11 Klick and Markowits (2008) use the suicide rate in age 25-64 group. Gender-age-grouped suicide rates are used in Chen et al. (2008, 2009a), Jungeilges (2002), and Rodríguez (2005). Suicide rates by gender groups are used in Chen et al. (2008), Chuang (2003), Huaung (1996), Koo and Cox (2008), Mäkinen (1997), Minoiu and Rodríguez (2008), Neumayer (2003), Rodríguez (2006), Stack (1998), and Watanabe et al. (2006).

12 Barnes (1975), Faupel et al. (1987), Lester (1995), and Zhang (1988) use the suicide rate in each location. Zhang (1988) treats the suicide rate in each developed or developing country. Cutler et al. (2000) and Freeman (1998) focus on the suicide rate of the youth.

13 Chen et al. (2008, 2009a), Minoiu and Rodríguez (2008), Rodríguez (2005, 2006), and Simpson and Conklin (1989) use the natural log of suicide rate. Burr et al. (1994), Chuang and Huang (2003), Cutler et al. (2000), Daly and Wilson (2006), Faupel et al. (1987), Freeman (1998), Klick and Markowitz (2003), Neumayer (2003), Helliwell (2007), Huang (1996), Stack (1997), Watanabe et al. (2006), and Zhang (1998) use the suicide rate per 100,000 people. Barnes (1975) uses the suicide rate per person in counties. Jungeilges and Kirchgassner (2002), Kimenyi and Shughart (1986), Lester (1995), Mäkinen (1997), and Viren (2005) use the suicide rate but do not specify which one. Lewis and Sloggett (1998) use the numbers of suicides. Ford and Kaserman (2000) use a binary variable if each patient committed suicide.

14 Instead of using GDP growth as a proxy for economic growth, Burr et al. (1994) use growth in new housing construction as a measure of economic vitality and population stability. They show that the coefficients of growth in new housing construction have a significantly positive effect on suicide rates in 294 metropolitan areas in the U.S.

15 It is by no means comprehensive and is mainly based on the authors' own research for the Studies on Suicide (SOS) project of the University of Tokyo (http://www2.e.u-tokyo.ac.jp/ scd_proj/main3.html).

16 A similar story from the state of Andhra Pradesh in India was also mentioned in a book by Ito (2007).

17 This may be due to the selection problem caused by differences in income, health, etc. between insured and uninsured people; the screening capability of the insurer is also a reason.

18 Exceptions are cases of high levels of life insurance density with negative relationships between suicide rates and life insurance densities, which may be explained by the wealth effect. This result challenges the current view that problems associated with asymmetric information are less likely to occur in life insurance markets.

19 Murder-Suicide in California: A Tragedy of the Financial Crisis? http://www.time.com/time/nation/article/0,8599,1848422,00.html. 
20 The most recent of the government's effort to reduce the suicide rate was the enactment of the "Basic Law of Suicide Prevention" in June 2006; the Cabinet Office also outlined comprehensive suicide-prevention guidelines in June 2007, setting a reduction target of at least 20\% by 2016.

\section{References}

Abbring, J. H., James J. Heckman, Pierre-André Chiappori, and Jean Pinquet. (2003) Adverse Selection and Moral Hazard in Insurance: Can Dynamic Data Help to Distinguish? Journal of the European Economic Association 1(2-3): 512-521.

Allebeck, P., Brandt, L., Nordstrom, P., and Åsgård, U. (1996) Are Suicide Trends among the Young Reversing? Acta Psychiatrica Scandinavica 93: 43-48.

Amamiya, K. (2002) Costs of Suicide [jisatsu No Kosuto, in Japanese], Ohta Shuppan.

Ardener, S. (1964) The Comparative Study of Rotating Credit Associations. Journal of the Royal Anthropological Society of Great Britain and Ireland 92(2): 201-229.

Armendaríz de Aghion, B. and Morduch, J. (2005) The Economics of MicroFinance, Cambridge: MIT Press.

Barnes, C. B. (1975) The Partial Effect of Income on Suicide is Always Negative. The American Journal of Sociology 80(6): 1454-1462.

Beautrais, A. L. (2001) Effectiveness of Barriers at Suicide Jumping Sites: A Case Study. Australian and New Zealand Journal of Psychiatry 35(5): 557-562.

Besley, T. (1995) Savings, Credit and Insurance. In J. Behrman and T.N. Srinivasan (ed.) Handbook of Development Economics Volume III (pp. 2123-2207), Amsterdam: North Holland.

Besley, T. and Coate, S. (1995) Group Lending, Repayment Incentives, and Social Collateral. Journal of Development Economics 46(1): 1-18. 
Blanchflower, David G. and Oswald, Andrew J. (2004) Well-being Over Time in Britain and the USA. Journal of Public Economics 88(7-8): 1359-1386.

Brainerd, E. (2001) Economic reform and mortality in the former Soviet Union: A study of the suicide epidemic in the 1990s, European Economic Review, 45(4-6): 1007-1019

Brent, D. A., Perper, J. A., Goldstein, C. E., Kolko, D. J., Allan, M. J., Allman, C J., and Zelenak, J. P. (1988) Risk Factors for Adolescent Suicide: A Comparison of Adolescent Suicide Victims with Suicidal Inpatients. Archives of General Psycbiatry 45: 581-588.

Brent, D. A., Perper, J. A., Allman, C. J., Moritz, G. M., Wartella, M. E., and Zelenak, J. P. (1991) The Presence and Accessibility of Firearms in the Homes of Adolescent Suicides: A Case-control Study. Journal of the American Medical Association 266: 2989-2995.

Brent, D. A., Perper, J. A., Allman, C. J., Moritz, G. M., Wartella, M. E., and Zelenak, J. P. (2001) The Presence and Accessibility of Firearms in the Homes of Adolescent Suicides: A Case-control Study. Journal of the American Medical Association 266(21): 2989-2995.

Burr, J. A., McCall, P. L., and Powell-Griner, E. (1994) Catholic Religion and Suicide: The Mediating Effect of Divorce. Social Science Quarterly 75(2): 300-318.

Cabinet Office. (2007) Whitepaper on Suicide Prevention Policies 2007, the Cabinet Office, Government of Japan.

Carrington, P. J. and Moyer, S. (1994) Gun Control and Suicide in Ontario. American Journal of Psychiatry 151: 606-608.

Centers for Disease Control and Prevention. (2001) Preventing Suicide. Available at: http://www.cdc.gov/ncipc/dvp/Preventing Suicide.pdf.

Chen, J., Choi, Y., and Sawada, Y. (2007) Joint Liability Borrowing and Suicide, Center for International Research on the Japanese Economy Discussion Papers, CIRJE-F-534, University of Tokyo.

----- (2008) Suicide and Life Insurance, Center for International Research on the Japanese Economy Discussion Papers, CIRJE-F-558, University of Tokyo. 
----- (2009a) How is Suicide Different in Japan? Japan and the World Economy 21(2): 140-150.

Chen, J., Choi, Y., K. Mori, Sawada, Y., and Sugano, S. (2009b) Those Who are Left Behind: An Estimate of the Number of Family Members of Suicide Victims in Japan. Social Indicators Research doi: 10.1007/s11205-009-9448-3.

Chew, K. S. Y. and Mccleary, R. (1995) The Spring Peak in Suicides: A Cross-national Analysis. Social Science and Medicine 40(2): 223-230.

Chiappori, Pierre-Andre, Bruno Jullien, Bernard Salanie, and Francois Salanie. (2006) Asymmetric Information in Insurance: General Testable Implications. Rand Journal of Economics 37: 783-798.

Chuang, H. and Huang, W. (2003) Suicide and Unemployment: Is There a Connection? An Empirical Analysis of Suicide Rates in Taiwan. Journal of Socio-Economics 26(3): 277-289.

Cutler, D. M., Glaeser, E., and Norberg, K. (2000) Explaining the Rise in Youth Suicide. NBER working paper No. 7713.

Daly, M. C. and Wilson, D. J. (2006) Keeping Up with the Joneses and Staying Ahead of the Smiths: Evidence from Suicide Data. FRB of San Francisco Working Paper 2006-12.

Dixit, A. K., and Pindyck, R. S. (1994) Investment under Uncertainty, Princeton: Princeton University Press.

Durkheim, E. (1897) Le Suicide: Etude de sociologie, Paris: Alcan (translated by J. A. Spaulding, J. A. and G. Simpson, Suicide: A Study in Sociology, New York, Free Press 1951).

Edwin, S. S. (2001) Comprehending Suicide: Landmarks in the 20th- Century Suicidology. Crisis: The Journal of Crisis Intervention and Suicide 22(2): 79

Esterlin, R. (1974) Does Economic Growth Improve the Human lot? Some Empirical Evidence. In David, R. and Reder, R. (Eds.), Nationans and Households in Economic Growth: Essays in Honor of Moses Abramovitz. New York: Academic Press.

Faupel, C. E., Kowalski, G. S., and Starr, P. D. (1987) Sociology's One Law: Religion and Suicide in the Urban 
Context. Journal for the Scientific Study of Religion 26: 523-534.

Ferri, E. (1917) Criminal sociology. Boston: Little, Brown.

Ford, J. M. and Kaserman, D. L. (2000) Suicide as an Indicator of Quality of Life: Evidence from Dialysis Patients. Contemporary Economic Policy 18: 440-449.

Freeman, D. G. (1998) Determinants of Youth Suicide: The Easterlin-Holinger Cohort Hypothesis Re-examined. American Journal of Economics and Sociology 57: 183-200.

Ghatak, M. (2000) Screening by the Company You Keep: Joint Liability Lending and the Peer Selection Effect. Economic Journal, 110: 601-631.

Gould, M., Petrie, K., Kleinman, M. H., and Wallenstein, S. (1994) Clustering Attempted Suicide: New Zealand National Data, International Journal of Epidemiology 23: 1185-1189

Granizo, J. J., Guallar, E., and Rodriguez-Artalejo, F. (1996) Age-period-cohort Analysis of Suicide Mortality Rates in Spain, 1959-1991. International Journal of Epidemiology 25: 814-820.

Gunnell, D., N. Middleton, E. Whitley, D. Dorling, and S, Frankel. (2003) Influence of Cohort Effects on Patterns of Suicide in England and Wales, 1950-1999. British Journal of Psychiatry 182: 164-170.

Hamermesh, D. S., and Soss, N. M. (1974) An economic theory of suicide. The journal of political economy 82(1): 83-98.

Helliwell, J. H. (2007) Well-Being and Social Capital: Does Suicide Pose a Puzzle? Social Indicators Research 81: 455-496.

Henry, A. F. and Short, J. F. (1954) Suicide and Homicide. New York: Free Press of Glencoe.

Huang, W. (1996) Religion, Culture, Economic and Sociological Correlates of Suicide Rates: A Cross-national Analysis. Applied Economics Letters 3: 779-782.

Ito, Y. (2007) Information Technology and Caste in India: Its Growth Secret and Agony [IT To Caste: India Seicho No Himitsu To Kunou in Japanese] Nihon Keizai Shumbun Sha. 
Jungeilges, J. and Kirchgassner, G. (2002) Economic Welfare, Civil Liberty, and Suicide: An Empirical Investigation. The Journal of Socio-Economics 31 (3): 215-231.

Kellerman, A. L., Lee, R. K, Mercy, J. A., and Banton, J. (1991) The Epidemiologic Basis for the Prevention of Firearm Injuries. Annual Review of Public Health 12: 17-40.

Kendell, R. E. (1970) Relationship between Aggression and Depression. Archives of General Psychiatry 22: $308-318$.

Kimenyi, M. S. and Shughart, W. F. (1986) Economics of Suicide: Rational or Irrational Choice. Atlantic Economic Journal 14(1): 120-121.

Klick, J. and Markowitz, S. (2003) Are Mental Health Insurance Mandates Effective? Evidence from Suicides. NBER Working Paper No. 9994.

Koo, J. and Cox, W. M. (2008) An Economic Interpretation of Suicide Cycles in Japan. Contemporary Economic Policy 26: 162-174.

Kreitman, N. (1976) The Coal Gas Story: United Kingdom Suicide Rates, 1960-1971. British Journal of Social and Preventive Medicine 30: 86-93.

LaVecchia, C., Bollini, P., Imazio, C., and Decarli, A. (1986) Age, Period and Birth Cohort Effects on Suicide Mortality in Italy, 1955-1979. Acta Psychiatrica Scandinavica 74(2): 137-143

Leenaars, A. A., Kral, M. J., and Dyck, R. J. (1998) Suicide in Canada. Toronto: University of Toronto Press

Lester, D. (1995) Explaining Regional Differences in Suicide Rates. Social Sciences and Medicine 40(5): 719-721.

Lewis, G. and Sloggett, A. (1998) Suicide, Deprivation, and Unemployment: Record Linkage Study. British Medical Journal 317: 1283-1286.

Loftin, C., McDowall, D., Wiersema, B., and Cottey, T. J. (1991) Effects of Restrictive Licensing of Handguns on Homicide and Suicide in the District of Columbia. New England Journal of Medicine 325: 1615-1649. 
Mäkinen, I. (1997) Are There Social Correlates to Suicide? Social Science and Medicine 44: 1919-1929.

Mann, J. J., Apter, A., Bertolote, J., Beautrais, A., Currier, D., Haas, A., Hegerl, U., Lonnqvist, J., Malone, K., Marusic, A., Mehlum, L., Patton, G., Phillips, M., Rutz, W., Rihmer, Z., Schmidtke, A., Shaffer, D., Silverman, M., Takahashi, Y., Varnik, A., Wasserman, D., Yip, P., and Hendin, H. (2005) Suicide Prevention Strategies: A Systematic Review. Journal of American Medical Association 294: 2064-2074.

Marcotte, D. E. (2003) The Economics of Suicide, Revisited, Southern Economic Journal 69(3): 628-643.

Maskill, C., McClellan, V., Hodges, I., and Collings S. (2005) Explaining Patterns of Suicide. A Selective Review of Studies examining Social, Economic, Cultural and other Influences. Social explanations for suicide in New Zealand Volume I, Ministry of Health, Public Health Directorate.

McIntosh, J. L. (2008), U.S.A. Suicide: 2005 Official Final Data. Available at: www.suicidology.org/c/document library/get file?folderId=228\&name=DLFE-25.pdf.

Mckenna, C., Kelleher, M. J., and Corcoran, P. (1997) Suicide, Homicide and Crime in Ireland: What are the Relationships? Archives of Suicide Research 3 (1): 53-64.

Miao, J.,and Wang, N. (2007) Risk, uncertainty, and option exercise. Working Paper, Boston University and Columbia University.

Mitford, A. B. (1871) Appendix A: An Account of the Hara-Kiri (From a Rare Japanese Ms.). In Tales of Old Japan (pp. 267-269). London: MacMillan

Minoiu, C. and Rodríguez, A. (2008) The Effect of Public Spending on Suicide: Evidence from U.S. State Data. The Journal of Socio-Economics 37: 237-261.

Moens, G. F. G., van Oortmarssen, G. J., Honggokoesoemo, S., and van de Voorde, H. (1987) Birth Cohort Analysis of Suicide Mortality in Belgium, 1954-1981, by a Graphic and a Quantitative method. Acta Psychiatrica Scandinavica 76: 450-455.

Morselli, E. (1882) Suicide: An Essay in Comparative Moral Statistics. New York: Appleton. 
Murphy, G. E. and R. D. Wetzel. (1980) Suicide Risk by Birth Cohort in the United States, 1949-1974. Archives of General Psychiatry 37: 519-523.

Neumayer, E. (2003) Are Socioeconomic Factors Valid Determinants of Suicide? Controlling for National Cultures of Suicide with Fixed-Effects Estimation. Cross-Cultural Research 37 (3): 307-329.

O'Carroll, P. W. and Silverman, M. M. (1994) Community Suicide Prevention: The Effectiveness of Bridge Barriers. Suicide \& Life-threatening Behavior 24(1): 89-91.

Petronis, K. R., Samuels, J. F., Moscicki, E. K., and Anthony, J. C. (1990) An epidemiologic investigation of potential risk factors for suicide attempts. Social Psychiatry and Psychiatric Epidemiology 25(4): 193-199

Reisch, T., U. Schuster, and K. Michel. (2007) Suicide by Jumping and Accessibility of Bridges: Results from a National Survey in Switzerland. Suicide \& Life-threatening Behavior 37(6): 681-687.

Rodríguez, A. (2005) Income Inequality, Unemployment, and Suicide: A Panel Data Analysis of 15 European countries. Applied Economics 37: 439-451.

Rodríguez, A. (2006) Inequality and Suicide Mortality: A Cross-Country Study, Development Research Working Paper Series 13/2006, Institute for Advanced Development Studies.

Rosenthal, R. W. (1993) Suicide Attempts and Signaling Games. Mathematical Social Sciences 26: 25-33.

Sawada, Y., K. Nawata, M. Ii, and J. J. Lee. (2007) Did the Credit Crunch in Japan Affect Household Welfare? An Augmented Euler Equation Approach Using Type-5 Tobit Model, CIRJE Discussion Papers F-Series CIRJE-F-498, CIRJE, Faculty of Economics, University of Tokyo.

Simpson, M. and Conklin, G. (1989) Socioeconomic Development, Suicide and Religion: A Test of Durkheim's Theory of Religion and Suicide. Social Forces 67: 945-964.

Skegg, K. and Cox, B. (1991) Suicide in New Zealand, 1957-1986: The Influence of Age, Period and Birth-cohort. Australian and New Zealand Journal of Psycbiatry Psycbiatry 25: 181-190.

Solomon, M. L. and Hellon, C. P. (1980) Suicide Risk by Birth Cohort in Alberta, Canada. Archives of General Psychiatry Psychiatry 37: 511-513. 
Sommers, P. M. (1984) The Effect of Gun Control Laws on Suicide Rates. Atlantic Economic Journal 12 (1): $67-69$.

Stack, S. (1998) The relationship of female labor force participation to suicide: A comparative analysis. Archives of Suicide Research 4: 249-261.

Stack, S. (2000) Media Impacts on Suicide: A Quantitative Review of 293 findings. Social Science Quarterly 81: 957-971.

Stiglitz, J. (1990) Peer Monitoring and Credit Markets. World Bank Economic Review 4(3): 351-366.

Suicide Investigation Team. (2008) Whitepaper on Suicide Reality 2008 (in Japanese).

Suzuki, T. (2008) Economic Modelling of Suicide Under Income Uncertainty: For Better Understanding of Middle-Aged Suicide. Australian Economic Papers 47(3): 296-310.

Toyokawa, Y. and Shirouzu, T. (1998) On the Recent Trend in Suicide Rate [Saikin No Jisatsu-Ritsu No Doukou Ni Tsuite, in Japanese]. Journal of the Association of Life Insurance Medicine of Japan 96: 143-148.

Tseng, S. H. (2006) The Effect of Life Insurance Policy Provisions on Suicide Rates, in Chapter 2, Ph.D. dissertation, Three Essays on Empirical Applications of Contract Theory, Department of Economics, University of Chicago.

Villeneuve, B. (2000) Life Insurance. In G. Dionne (ed. ) Handbook of Insurance (pp. 901-932). Amsterdam: North Holland.

Viren, M. (2005) Suicide and Business Cycles: New Empirical Evidence. Applied Economics Letters 12: $887-891$.

Watanabe, R., Furukawa, M., Nakamura, R., and Ogura, Y. (2006) Analysis of the Socioeconomic Difficulties Affecting the Suicide Rate in Japan. Kyoto Institute of Economic Research Discussion Paper

West, M. (2003) Dying to Get Out of Debt: Consumer Insolvency Law and Suicide in Japan. The John M. Olin Center for Law and Economics Working Paper Series, No. 21, University of Michigan Law School. 
Wilkinson, R. G. (1997) Health Inequalities: Relative or Absolute Material Standards? British Medical Journal 314(7080): 591-595.

Woo, D. (2003) In Search of "Credit Crunch": Supply Factors behind the Credit Slowdown in Japan. Journal of Money, Credit and Banking 5(6): 1091-1038.

WHO (1986), Suicide in Suriname, Epidemiologic Record, August 8, 1986. Geneva: World Health Organization Weekly.

WHO (2000) Preventing Suicide. A Resource for Media Professionals. World Health Organization $\mathrm{WHO} / \mathrm{MNH} / \mathrm{MBD} / 00.2$.

WHO (2007) World Suicide Prevention Day, World Health Organization, September 10, 2007. http://www.who.int/dediacentre/news/statements/2007/s16/en.print.html.

Yang, B. and Lester, D. (1993) Is Suicide a Rational Behavior? Atlantic Economic Journal 21(3): 95

Zhang, J. (1998) Suicide in the World: Toward a Population Increase Theory of Suicide. Death Studies 22: 525-539. 
Table 1 A Summarv of Existing Studies: Dataset and Dependent Variable:

\begin{tabular}{|c|c|c|c|c|c|c|c|c|}
\hline Authors & $\begin{array}{l}\text { Pub. } \\
\text { Year }\end{array}$ & Area & Year & $\begin{array}{l}\text { panel/ cross- } \\
\text { section }\end{array}$ & $\begin{array}{l}\text { aggregate/ } \\
\text { individual }\end{array}$ & $\begin{array}{l}\mathrm{N} \text { of } \\
\text { observation }\end{array}$ & Method & dependent variables \\
\hline Barnes & 1975 & 3,077 counties in US & N.A. & cross-section & aggregate & 3,077 & OLS & suicide rates \\
\hline Burr et al. & 1994 & 294 metropolitan area & 1980 & cross-section & aggregate & 294 & OLS & age-standardized suicide rates \\
\hline Chen et al. & 2008 & OECD countries & $1980-2003$ & panel data & aggregate & 312 & Fixed effects & age-standardized male/female/sub-age group suicide rates \\
\hline Chen et al. & 2009 & OECD countries & $1980-2003$ & panel data & aggregate & 259 & Semiparametric IV regression with fixed effects & age-standardized suicide rates \\
\hline Chew and McCleary & 1995 & 28 countries & 1960s-1980s, ${ }^{\text {a) }}$ & panel data & aggregate & & Zero-order correlations & seasonal suicide fluctuation \\
\hline Chuang and Haung & 2003 & 23 cities and counties in Taiwan & $1983-2001$ & panel data & aggregate & 23 & OLS, GLS, Fixed effects & total/male/female suicide rates \\
\hline Culter et al. & 2001 & US 49 states & $1950-1990$ & cross-section & aggregate & 49 & OLS & total/youth male/youth femal/youth suicide rates change \\
\hline Daly and Wilson & 2006 & US & 1990,2000 & cross section & aggregate & 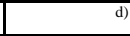 & GLS & suicide rates \\
\hline Faupel and Kaserman & 1987 & 3,108 counties in US & $1974,1975,1976$ & cross-section & aggregate & 1,039 & OLS & suicide rates \\
\hline Ford and Kaserman & 2000 & dialysis patients in US & 1997 & cross-section & individual & 454,076 & 2SLS & dummy variable $=1$ if patient committed suicide,zero otherwise \\
\hline Freeman & 1998 & US & 1959-1993 & panel data & aggregate & N.A. & OLS & youth suicide rates \\
\hline Helliwell & 2007 & 117 nations & 1980s-1990s & cross-section & aggregate & 117 & OLS & suicide rates \\
\hline Huang & 1996 & 48 countries & 1990 & cross-section & aggregate & 48 & OLS & total/male/female suicide rates \\
\hline Jungeilges and Kirchgassner & 2002 & 30 countries & 1975 & cross-section & aggregate & 30 & SUR & male/female suicide rates \\
\hline Kimenyi and Shughart & 1986 & US & $1940-1980$ & panel data & aggregate & N.A. & OLS & suicide rates \\
\hline Koo and Cox & 2008 & Japan & $1950-2003$ & time-series & aggregate & N.A. & Time-series & age-adjusted male/female suicide rates \\
\hline Lester & 1995 & 48 continental states of US & 1959-1961 & panel data & aggregate & N.A. & Pearson correlation analysis & suicide rates, ${ }^{\mathrm{e})}$ \\
\hline Mäkinen & 1997 & 17 European countries & 1977-1979/1988-1990 & panel data & aggregate & N.A. & Correlation anaylsis & total/male/female suicide rates \\
\hline Marcotte & 2003 & US aged $18-54$ & 1991,1992 & cross-section & individual & 5,877 & OLS & individual annual income \\
\hline Klick and Markowitz & 2003 & US & $1981-2000$ & panel data & aggregate & N.A. & OLS, 2SLS & adult suicides rates \\
\hline Minoiu and and Rodríguez & 2008 & 47 US states & 1982-1997 & panel data & aggregate & 665 & System GMM estimation & age-adjusted total/male/female suicide rates \\
\hline Neumayer & 2003 & 68 countries & 1980-1999 & panel data & aggregate & 788 & Fixed effects and random effects models & male/female suicide rates \\
\hline Rodríguez & 2005 & 15 European countries & 1970-1998 & panel data & aggregate & 236 & Fixed effects & male and female suicide rates \\
\hline Rodríguez & 2006 & 40 countries & $1947-2001$ & panel data & aggregate & 296 & Fixed effects & total/male/female suicide rates \\
\hline Simpson and Conklin & 1989 & 71 countries & 1970 & cross-section & aggregate & 71 & OLS & total/male/female suicide rates \\
\hline Stack & 1998 & 53 countries & 1980 & cross-section & aggregate & 53 & OLS & total/male/female suicide rates \\
\hline Watanabe et al. & 2006 & Japan & $1993-2004,{ }^{\text {b) }}$ & panel data & aggregate & $88-329$ & OLS, time-series & age adjusted total/male/female suicide rates \\
\hline Zhang & 1988 & 60 countries & $1980-1986$ & cross-section & aggregate & 60 & Factor analysis,OLS & developing/developed countries suicide rates \\
\hline
\end{tabular}

Notes:

Monthly suicide data. The data spans vary in countries.

b) Some years drop.

c) The number of observation varies in countries.

d) $24,665-27,750$

e) Total/Born-in-state/Born-out-of-state/non-continougs state/foreign born suicide rates 
Table 2 A Summary of Existing Studies: Estimation Results

\begin{tabular}{|c|c|c|c|c|c|c|c|c|c|c|c|}
\hline \multirow{2}{*}{ Authors } & \multirow{2}{*}{$\begin{array}{l}\text { Pub. } \\
\text { Year }\end{array}$} & \multirow{2}{*}{ dependent variables } & \multicolumn{3}{|c|}{ Income/real GDP per capita } & \multicolumn{3}{|c|}{ income inequality(Gini) } & \multicolumn{3}{|c|}{ economic growth } \\
\hline & & & total & male & female & total & male & female & total & male & female \\
\hline Barnes, ${ }^{\text {a) }}$ & 1975 & suicide rates &,+- & & & & & & & & \\
\hline Burr et al. , ${ }^{\text {a) }}$ & 1994 & age-standardized suicide rates & $+*$ & & & & & & $+*$ & & \\
\hline Chen et al., b) & 2008 & age-standardized male/female/sub-age group suicide rates & & $-*$ & $-*$ & & $+*$ & + & & $1^{-}$ & - \\
\hline Chen et al. , ${ }^{\text {c) }}$ & 2009 & age-standardized suicide rates & $-*$ & & & $+*,-*$ & & &,+- & & \\
\hline Chew and McCleary & 1995 & seasonal suicide fluctuation & -* & -* & - & & & & & & \\
\hline Chuang and Haung & 2003 & total/male/female suicide rates & $-*$ & $-*$ & $-*$ & & & & & & \\
\hline Culter et al., ${ }^{\text {d) }}$ & 2001 & total/youth male/youth femal/youth suicide rates change &,$+-{ }_{y}$ & $-*$ & - & & & & & & \\
\hline Daly and Wilson, ${ }^{\mathrm{e}, \mathrm{f})}$ & 2006 & suicide rates & $-*$ & & & $-*,-,+^{*}$ & & & & & \\
\hline Faupel and Kaserman & 1987 & suicide rates (in the least/middle/most urban) & $-1 /-* /-*$ & & & $+1+* /+*$ & & & & & \\
\hline Ford and Kaserman & 2000 & dummy variable $=1$ if patient committed suicide,zero other & wise & & & & & & & & \\
\hline Freeman, ${ }^{\text {a) }}$ & 1998 & youth suicide rates & $+*$ & & & $+*,+$ & & & & & \\
\hline Helliwell, ${ }^{\text {a) }}$ & 2007 & suicide rates & $-*$ & & & & & & & & \\
\hline Huang & 1996 & total/male/female suicide rates & - & - & $-*$ & & & & & & \\
\hline Jungeilges and Kirchgassner, ${ }^{\mathrm{g})}$ & 2002 & male/female sub-age group suicide rates & & $+*$ & $+*,-*,+,-$ & & & & & $+*,+$ & $+*,+$ \\
\hline Kimenyi and Shughart, ${ }^{\text {a) }}$ & 1986 & suicide rates & $-*$ & & & & & & & & \\
\hline Koo and Cox, ${ }^{\text {c) }}$ & 2008 & age-adjusted male/female suicide rates & & & & & & & & & \\
\hline Lester, $^{\text {h) }}$ & 1995 & suicide rates & $+*,+$ & & & & & & & & \\
\hline Mäkinen & 1997 & total/male/female suicide rates & & & & & & & & & \\
\hline Marcotte & 2003 & individual annual income & & & & & & & & & \\
\hline Klick and Markowitz, ${ }^{\text {c) }}$ & 2003 & adult suicides rates & - & & & & & & & & \\
\hline Minoiu and and Rodríguez & 2008 & age-adjusted total/male/female suicide rates & - & $-{ }_{-*}$ & + & + & + & + & & & \\
\hline Neumayer & 2003 & male/female suicide rates & & $-*$ & - & & & & & + & - \\
\hline Rodríguez & 2005 & male/female sub-age group suicide rates & & $+*,-$ & $+*,-$ & & $+*,+$ & $-*,-$ & & + & - \\
\hline Rodríguez & 2006 & total/male/female suicide rates & - & + & $-*$ & - & $+*$ & $-*$ & & & \\
\hline Simpson and Conklin & 1989 & suicide rates & $+*$ & & & & & & & & \\
\hline Stack & 1998 & total/male/female suicide rates & & & & & & & + & + & + \\
\hline Watanabe et al., ${ }^{\text {c) }}$ & 2006 & age adjusted total/male/female suicide rates & & & & & & & & & \\
\hline Zhang, ${ }^{\text {a) }}$ & 1988 & developing/developed countries suicide rates & & & & & & & & & \\
\hline
\end{tabular}

The superscript "*" indicates statistical significance. 
Table 2 A Summary of Existing Studies: Estimation Results (continued.)

\begin{tabular}{|c|c|c|c|c|c|c|c|c|c|c|c|c|c|c|c|c|}
\hline \multirow{2}{*}{ Authors } & \multirow{2}{*}{$\begin{array}{l}\text { Pub. } \\
\text { Year }\end{array}$} & \multicolumn{3}{|c|}{ education } & \multicolumn{3}{|c|}{ unemployment } & \multicolumn{3}{|c|}{$\begin{array}{c}\text { female labor } \\
\text { participation rate }\end{array}$} & \multicolumn{3}{|c|}{ divorce rate } & \multicolumn{3}{|c|}{ marriage rate } \\
\hline & & total & male & female & total & male & female & total & male & female & total & male & female & total & male & female \\
\hline Barnes, ${ }^{\text {a) }}$ & 1975 & $+*,+,-$ & & & & & & & & & & & & & & \\
\hline Burr et al. , a) & 1994 & & & &,+- & & & $-*,-$ & & & $+*$ & & & & & \\
\hline Chen et al. , b) & 2008 & & & & & - & + & & - & - & & + & + & & & \\
\hline Chen et al. , c) & 2009 & & & &,+- & & & $+*,+,-$ & & & $+*,+$ & & & & & \\
\hline Chew and McCleary & 1995 & & & & & & & & & & & & & & & \\
\hline Chuang and Haung & 2003 & & & & $+*$ & $+*$ & - & + & + & + & $+*$ & $+*$ & $+*$ & & & \\
\hline Culter et al., ${ }^{\text {d) }}$ & 2001 & & & & & & &,$-+{ }_{y}$ & $+*$ & + & + & & & & & \\
\hline Daly and Wilson, e), f) & 2006 & $-*,-$, i) & & & $+*,+$ & & & & & & & & & $-*$ & & \\
\hline Faupel and Kaserman & 1987 & $+/+* /+*$ & & & $+/+* /+$ & & & $+/-* /-*$ & & & $+/+/+*$ & & & & & \\
\hline Ford and Kaserman & 2000 & & & & & & & & & & & & & & & \\
\hline Freeman, ${ }^{\text {a) }}$ & 1998 & & & & $+*,+$ & & & & & & $+*$, & & & & & \\
\hline Helliwell, ${ }^{\text {a) }}$ & 2007 & & & & & & & & & & $+*$ & & & & & \\
\hline Huang & 1996 & & & & $+*$ & $+*$ & + & & & & - & - & - & & & \\
\hline Jungeilges and Kirchgassner, ${ }^{\text {g) }}$ & 2002 & & & & & & & & & & & & & & & \\
\hline Kimenyi and Shughart, ${ }^{\text {a) }}$ & 1986 & & & & $+*$ & & & & & & $+*$ & & & & & \\
\hline Koo and Cox, ${ }^{\text {c) }}$ & 2008 & & & & & $+*$ & $+*$ & & $+*$ & $+*,+$ & & $+*$ & $+*,-$ & & & \\
\hline Lester, $^{\text {h) }}$ & 1995 & & & &,+- & & & & & & $+*$, + & & & $+*,+$ & & \\
\hline Mäkinen & 1997 &,,$\left.-^{j}\right)$ & - & - & - & $-*$ & - & $+*$ & $+*$ & + & $+*$ & $+*$ & $+*$ & + & + & - \\
\hline Marcotte & 2003 & $+*, \mathrm{k})$ & & & & & & & & & & & & & & \\
\hline Klick and Markowitz, ${ }^{\text {c) }}$ & 2003 & $-*,-$ & & & $+*$ & & & $+*,+$ & & & & & & & & \\
\hline Minoiu and and Rodríguez & 2008 & & & & + & + & + & & & & $+*$ & $+*$ & $+*$ & & & \\
\hline Neumayer & 2003 & & & & & + & - & & + & $+*$ & & $+*$ & $+*$ & & $-*$ & $-*$ \\
\hline Rodríguez & 2005 & & & & & $+*,+$ & $+*,+$ & & $+*,+$ & $+*,+$ & & $+*$ & + & & & \\
\hline Rodríguez & 2006 & & & & & & & - & $+*$ & $+*$ & $-*$ & - & $-*$ & & & \\
\hline Simpson and Conklin & 1989 & & & & & & & + & & & & & & & & \\
\hline Stack & 1998 & & & & & & & $+*$ & $+*$ & $+*$ & & & & & & \\
\hline Watanabe et al., ${ }^{\text {c) }}$ & 2006 & & & & & $+*$ &,+- & & & & & $+*,+,-$ & + & & & \\
\hline Zhang, ${ }^{\text {a) }}$ & 1988 & & & & & & & & & & & & & & & \\
\hline
\end{tabular}

The superscript "*" indicates statistical significance. 
Table 2 A Summary of Existing Studies: Estimation Results (continued.)

\begin{tabular}{|c|c|c|c|c|c|c|c|c|c|c|c|c|c|c|c|c|}
\hline \multirow[t]{2}{*}{ Authors } & \multirow{2}{*}{$\begin{array}{l}\text { Pub. } \\
\text { Year }\end{array}$} & \multicolumn{3}{|c|}{ birth rate/ fertility rate } & \multicolumn{3}{|c|}{$\begin{array}{l}\text { social isolation/ one- } \\
\text { person households }\end{array}$} & \multicolumn{3}{|c|}{$\begin{array}{l}\text { average household } \\
\text { size }\end{array}$} & \multicolumn{3}{|c|}{ Population density } & \multicolumn{3}{|c|}{$\begin{array}{l}\text { proportion of youth } \\
\text { (age 15-19) }\end{array}$} \\
\hline & & total & male & female & total & male & female & total & male & female & total & male & female & total & male & female \\
\hline Barnes, ${ }^{\text {a) }}$ & 1975 & & & & & & & & & & & & & & & \\
\hline Burr et al. , a) & 1994 & & & & $+*$ & & & & & & $-*,-$ & & & & & \\
\hline Chen et al. , b) & 2008 & & + & + & & & & & & & & & & & & \\
\hline Chen et al. , ${ }^{\text {c) }}$ & 2009 & $+*,-$ & & & & & & & & & & & & & & \\
\hline Chew and McCleary & 1995 & & & & & & & & & & & & & & & \\
\hline Chuang and Haung & 2003 & & & & $-*$ & - & - & & & & & & & & & \\
\hline Culter et al., d) & 2001 & & & & & & & & & & & & & & & \\
\hline Daly and Wilson, ${ }^{\text {e), f) }}$ & 2006 & & & & $-*$ & & & $+*,+$ & & & & & & & & \\
\hline Faupel and Kaserman & 1987 & $+1-/-*$ & & & $-/+* /+*$ & & & & & & & & & & & \\
\hline Ford and Kaserman & 2000 & & & & & & & & & & & & & & & \\
\hline Freeman, ${ }^{\text {a) }}$ & 1998 & & & & & & & & & & & & & $+*$ & & \\
\hline Helliwell, ${ }^{\text {a) }}$ & 2007 & & & & $-*, n)$ & & & & & & & & & & & \\
\hline Huang & 1996 & & & & & & & & & & & & & & & \\
\hline Jungeilges and Kirchgassner, ${ }^{\text {g) }}$ & 2002 & & & & & & & & & & & & & & & \\
\hline Kimenyi and Shughart, ${ }^{\text {a) }}$ & 1986 & & & & & & & & & & & & & & & \\
\hline Koo and Cox, ${ }^{\text {c) }}$ & 2008 & & $-*,-$ & $-*,-$ & & & & & & & & & & & & \\
\hline Lester, $^{\text {h) }}$ & 1995 & $+*,+,-$ & & & & & & & & & & & & & & \\
\hline Mäkinen & 1997 & $-*, \mathrm{~m})$ & $-*$ & $-*$ &,$+^{0)}$ & + & + & & & & & & & _*, q) & $-*$ & $-*$ \\
\hline Marcotte & 2003 & & & & & & & & & & & & & & & \\
\hline Klick and Markowitz, ${ }^{c)}$ & 2003 & & & & & & & & & & & & & & & \\
\hline Minoiu and and Rodríguez & 2008 & & & & & & & & & & $-*$ & $-*$ & - & & & \\
\hline Neumayer & 2003 & & $-*$ & $-*$ & & & & & - & $-*$ & & & & & & \\
\hline Rodríguez & 2005 & & $-*$ & $-*$ & & & & & & & & & & & & \\
\hline Rodríguez & 2006 & $-*$ & $-*$ & $-*$ & & & & & & & & & & & & \\
\hline Simpson and Conklin & 1989 & & & & & & & & & & & & & & & \\
\hline Stack & 1998 & & & & & & & & & & & & & & & \\
\hline Watanabe et al., ${ }^{\text {c) }}$ & 2006 & & & & & & & & & & & & & & & \\
\hline Zhang, $^{\text {a) }}$ & 1988 & & & & & & & & & & $\left.-* /{ }_{-*}, \mathrm{p}\right)$ & & & & & \\
\hline
\end{tabular}

The superscript "*" indicates statistical significance. 
Table 2 A Summary of Existing Studies: Estimation Results (continued.)

\begin{tabular}{|c|c|c|c|c|c|c|c|c|c|c|c|c|}
\hline \multirow[t]{2}{*}{ Authors } & \multirow{2}{*}{$\begin{array}{l}\text { Pub. } \\
\text { Year }\end{array}$} & \multicolumn{3}{|c|}{$\begin{array}{l}\text { proportion of elderly } \\
\qquad(\text { age }>65)\end{array}$} & \multirow{2}{*}{$\begin{array}{l}\text { age } \\
\text { total }\end{array}$} & \multirow{2}{*}{$\begin{array}{c}\text { male } \\
\text { total }\end{array}$} & \multicolumn{3}{|c|}{ alcohol consumption } & \multicolumn{3}{|c|}{$\begin{array}{c}\text { Religion ( Catholic (C) , Protestant (P), } \\
\text { Muslim (M)) }\end{array}$} \\
\hline & & total & male & female & & & total & male & female & total & male & female \\
\hline Barnes, ${ }^{\text {a) }}$ & 1975 & & & & & & & & & & & \\
\hline Burr et al. , a) & 1994 & & & & & & & & & $\mathrm{C}:-*, \mathrm{P}:+,-$ & & \\
\hline Chen et al. , b) & 2008 & & & & & & & + & + & & & \\
\hline Chen et al. , c) & 2009 & & & & & & $+*,+$, & & & & & \\
\hline Chew and McCleary & 1995 & & & & & & & & & & & \\
\hline Chuang and Haung & 2003 & $+*$ & - & $+*$ & & & & & & & & \\
\hline Culter et al., ${ }^{\text {d) }}$ & 2001 & & & & & & & & & & & \\
\hline Daly and Wilson, ${ }^{\text {e), f) }}$ & 2006 & & & & $+*$ & $+*$ & & & & & & \\
\hline Faupel and Kaserman & 1987 & & & & $+1-/-*$ & & & & & $\mathrm{C}:+/-* /-^{*}$ & & \\
\hline Ford and Kaserman & 2000 & & & & $+*$ & $-*$ & & & & & & \\
\hline Helliwell, ${ }^{\text {a) }}$ & 2007 & & & & & & & & & $-*, s)$ & & \\
\hline Huang & 1996 & - & - & + & & & & & & C: $-*$ & C: $-*$ & C: - \\
\hline Jungeilges and Kirchgassner, ${ }^{\text {g) }}$ & 2002 & & & & & & & & & & & \\
\hline Kimenyi and Shughart, ${ }^{\text {a) }}$ & 1986 & & & & & & & & & & & \\
\hline Koo and Cox, ${ }^{\text {c) }}$ & 2008 & & & & & & & + &,+- & & & \\
\hline Lester, ${ }^{\text {h) }}$ & 1995 & & & &,+- & & & & & & & \\
\hline Mäkinen & 1997 & + & + & + & & & & & & & & \\
\hline Marcotte & 2003 & & & & $+*$ & $\left.-*,^{r}\right)$ & + & & & & & \\
\hline Klick and Markowitz, ${ }^{\text {c) }}$ & 2003 & & & & & & + & & & & & \\
\hline Minoiu and and Rodríguez & 2008 & & & & & & & & & & & \\
\hline Neumayer & 2003 & & & & & & & $+*$ & + & & $\mathrm{C}:+, \mathrm{M}:+$ & $\mathrm{C}:+, \mathrm{M}:+$ \\
\hline Rodríguez & 2005 & & & & & & & $+*,+$ & $+*,+,-$ & & & \\
\hline Rodríguez & 2006 & & & & & & $-*$ & $-*$ & - & & & \\
\hline Simpson and Conklin & 1989 & $+*$ & & & & + & & & & M: -* & & \\
\hline Zhang, ${ }^{\text {a) }}$ & 1988 & & & & & & & & & & & \\
\hline
\end{tabular}

The superscript "*" indicates statistical significance. 
Table 2 A Summary of Existing Studies: Estimation Results (continued.)

\begin{tabular}{|c|c|c|c|c|c|c|c|c|c|c|c|c|c|c|c|c|}
\hline \multirow[t]{2}{*}{ Authors } & \multirow[t]{2}{*}{$\begin{array}{l}\text { Pub. } \\
\text { Year }\end{array}$} & \multicolumn{3}{|c|}{$\begin{array}{c}\text { Ethnic Heterogeneity(E) (Black (B), Hispanic } \\
\text { (H), Aboriginal (A), Native American (N), } \\
\text { White(W), Other race }(O))\end{array}$} & \multicolumn{3}{|c|}{ in-migration rate } & \multicolumn{3}{|c|}{$\begin{array}{c}\text { agricultural } \\
\text { workforce/farm }\end{array}$} & \multicolumn{3}{|c|}{ urban } & \multicolumn{3}{|c|}{$\begin{array}{l}\text { Presence of Life-Line } \\
\text { Center }\end{array}$} \\
\hline & & total & male & female & total & male & female & total & male & female & total & male & female & total & male & female \\
\hline Barnes, ${ }^{\text {a) }}$ & 1975 & & & & & & & & & & & & & & & \\
\hline Burr et al. , a) & 1994 & $\mathrm{~B}:+,-, \mathrm{H}:{ }^{*},+$ & & & & & & & & & & & & & & \\
\hline Chen et al. , b) & 2008 & & & & & & & & & & & & & & & \\
\hline Chen et al. , ${ }^{c)}$ & 2009 & & & & & & & & & & & & & & & \\
\hline Chew and McCleary & 1995 & & & & & & & - & $+*$ & + & & & & & & \\
\hline Chuang and Haung & 2003 & A: $+*$ & A: $+*$ & A: $+*$ & $-*$ & $-*$ & $-*$ & & & & & & & $-*$ & $-*$ & $-*$ \\
\hline Culter et al., ${ }^{\text {d) }}$ & 2001 & B: -*, $-{ }_{y}, N:+,+_{y}$ & B: -, N: + & B: -, N: + & & & &,$--y$ & - & - & $+*,-y$ & - & + & & & \\
\hline Daly and Wilson, ${ }^{\text {e), f) }}$ & 2006 & $\mathrm{~B}:-^{*}, \mathrm{H}:+,-^{*},-, \mathrm{O}:-^{*},-$ & & & & & & & & & & & & & & \\
\hline Faupel and Kaserman & 1987 & B: - / -*/ - & & & $+/+* /+*$ & & & & & & $-1+* /-$ & & & & & \\
\hline Ford and Kaserman & 2000 & & & & & & & & & & & & & & & \\
\hline Helliwell, ${ }^{\text {a) }}$ & 2007 & & & & & & & & & & & & & & & \\
\hline Huang & 1996 & & & & & & & & & & & & & & & \\
\hline Jungeilges and Kirchgassner, ${ }^{\text {g) }}$ & 2002 & & & & & & & & & & & & & & & \\
\hline Kimenyi and Shughart, ${ }^{\text {a) }}$ & 1986 & & & & & & & & & & & & & & & \\
\hline Koo and Cox, ${ }^{c)}$ & 2008 & & & & & & & & & & & & & & & \\
\hline Lester, ${ }^{\text {h) }}$ & 1995 & & & & & & & & & & & & & & & \\
\hline Mäkinen & 1997 & & & & & & & & & & $\left.-*,{ }^{t}\right)$ & $-*$ & $-*$ & & & \\
\hline Marcotte & 2003 & $\mathrm{~W}:+*$ & & & & & & & & & & & & & & \\
\hline Klick and Markowitz, ${ }^{\text {c) }}$ & 2003 & B: $+*$ & & & & & & $+*,+$ & & & & & & & & \\
\hline Minoiu and and Rodríguez & 2008 & & & & - & - & - & & & & & & & & & \\
\hline Neumayer & 2003 & & $\mathrm{E}:+*$ & $\mathrm{E}:+*$ & & & & & & & & & & & & \\
\hline Rodríguez & 2005 & & & & & & & & & & & & & & & \\
\hline Rodríguez & 2006 & & & & & & & & & & & & & & & \\
\hline Simpson and Conklin & 1989 & & & & & & & & & & & & & & & \\
\hline Zhang, ${ }^{\text {a) }}$ & 1988 & & & & & & & & & & & & & & & \\
\hline
\end{tabular}

The superscript "*" indicates statistical significance. 
Table 2 A Summary of Existing Studies: Estimation Results (continued.)

\begin{tabular}{|c|c|c|c|c|c|c|c|c|c|c|c|}
\hline \multirow[t]{2}{*}{ Authors } & \multirow[t]{2}{*}{$\begin{array}{l}\text { Pub. } \\
\text { Year }\end{array}$} & \multicolumn{3}{|c|}{ Latitude (La) and Longitude (Lo) } & \multicolumn{3}{|c|}{$\begin{array}{c}\text { civil liberty } \\
\text { index/quality of } \\
\text { government }\end{array}$} & \multirow{2}{*}{\begin{tabular}{|c|}
$\begin{array}{c}\text { suicide } \\
\text { attempt }\end{array}$ \\
total \\
\end{tabular}} & \multicolumn{3}{|c|}{$\begin{array}{c}\text { Non-suicide Mortality } \\
\text { Rate }\end{array}$} \\
\hline & & total & male & female & total & male & female & & total & male & female \\
\hline Barnes, ${ }^{\text {a) }}$ & 1975 & & & & & & & & & & \\
\hline Burr et al. , ${ }^{\text {a) }}$ & 1994 & & & & & & & & & & \\
\hline Chen et al. , ${ }^{\text {c) }}$ & 2009 & & & & & & & & & & \\
\hline Chew and McCleary & 1995 & La: + & La: - & La: - & & & & & & & \\
\hline Chuang and Haung & 2003 & & & & & & & & & & \\
\hline Culter et al., ${ }^{\text {d) }}$ & 2001 & & & & & & & & & & \\
\hline Daly and Wilson, ${ }^{\text {e), f) }}$ & 2006 & & & & & & & & $+*$ & & \\
\hline Helliwell, ${ }^{\text {a) }}$ & 2007 & La: $+*$ & & & - & & & & & & \\
\hline Huang & 1996 & & & & & & & & & & \\
\hline Jungeilges and Kirchgassner, ${ }^{\text {g) }}$ & 2002 & & & & &,$++*$ &,$++*$ & & & & \\
\hline Kimenyi and Shughart, ${ }^{\text {a) }}$ & 1986 & & & & & & & & & & \\
\hline Koo and Cox, ${ }^{\text {c) }}$ & 2008 & & & & & & & & & & \\
\hline Lester, $^{\text {h) }}$ & 1995 & La: $+^{*},+$, Lo: $+^{*},-,+$ & & & & & & & & & \\
\hline Mäkinen & 1997 & & & & & & & & $+*$, w) & $+*$ & + \\
\hline Marcotte & 2003 & & & & & & & $+*$ & & & \\
\hline Klick and Markowitz, ${ }^{\text {c) }}$ & 2003 & & & & & & & & & & \\
\hline Zhang, ${ }^{\text {a) }}$ & 1988 & & & & & & & & & & \\
\hline
\end{tabular}

The superscript "*" indicates statistical significance. 
Table 2 A Summary of Existing Studies: Estimation Results (continued.)

Notes:

a) The multiple results here come from different independent variables.

b) The results of age-specific suicide rates are omitted here.

c) The results depend on the methods.

d) The subscript "y" indicates "change in youth total suicide rates".

e) The relative income measured as the ratio of the 90th to the 10th, 90th to the 50th and 50th to the 10th percentiles of the distribution of households income are included as analysis variables.

f) The result of 1990 and that of 2000 are different.

g) The multiple results here come from age-specific suicide rates.

h) The dependent variables are Total/Born-in-state/Born-out-of-state/noncontiguous state/foreign born suicide rates and the result might differ among these.

i) The share of people with collage degree

j) Women in tertiary education

k) Respondent attended 4 years of college, $(0 / 1)$

l) \% of families which is headed by single parents

m) Women $>35$ years old

n) Trust

o) Illegitimacy

p) Population growth

q) People $<15$ years old

r) Female

s) Total church membership (\%)

t) The number of TV set

u) Mountain state

v) Minimum sunshine hours

w) Homicide rate 